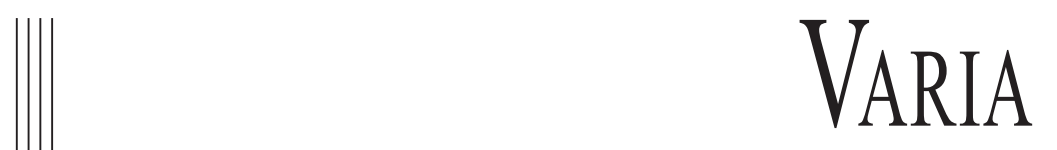

PRZEGLĄD SeJMOWY ～nr 5(154)/2019, s. 157-191; https://doi.org/10.31268/PS.2019.74

WOJCIECH KULISIEWICZ*

\title{
100 LAT BIBLIOTEKI SEJMOWEJ. TRADYCJA I NOWOCZESNOŚĆ
}

Biblioteka Sejmowa podjęła działalność jesienią 1919 r. Za jej akt założycielski uchodzi wniosek 18 posłów z partii ludowej (PSL „Piast”) złożony do marszałka Sejmu w marcu 1919 r. Zaczątkiem zbiorów były kolekcje książek o tematyce prawno-politycznej oraz zbiory przepisów pochodzące z różnych instytucji, które wraz z powstaniem państwa polskiego kończyły swoje istnienie (jak Wydział Krajowy galicyjski, Namiestnictwo we Lwowie, Tymczasowa Rada Stanu, b. Rejencja Poznańska), jak również donacje osób prywatnych. Przez cały okres dwudziestolecia międzywojennego Biblioteką Sejmową kierował Henryk Kołodziejski — z wykształcenia ekonomista, z zamiłowania bibliotekarz i działacz społeczny. Jego wysiłki pozwoliły do 1939 r. zgromadzić ok. 80 tys. woluminów ukierunkowanych tematycznie książek i czasopism. W 1931 r. utworzono Bibliotekę i Archiwum Sejmu i Senatu. Opierając się na strukturze Biblioteki, rozpoczęto porządkowanie i gromadzenie szybko zwiększającego się zasobu archiwalnego. Prowadzono również działalność wydawniczą oraz analityczno-ekspercką realizowaną przez powołane w tym samym roku referaty: prawny i społeczno-gospodarczy. W czasie II wojny światowej księgozbiór został wywieziony przez nazistów do Berlina, natomiast czasopisma i archiwalia uległy niemal całkowitemu zniszczeniu. Po wojnie powróciło nie więcej niż 11-12\% wywiezionych książek. W okresie rządów komunistycznych dzięki wysiłkowi bibliotekarzy udało się utrzymać dotychczasowy profil gromadzenia zbiorów, choć z licznymi ustępstwami na rzecz klasyków marksizmu-leninizmu. Prowadzono jednak stałą wymianę parlamentariów (również z państwami zachodnimi), znaczący był także wpływ wydawnictw obcojęzycznych zarówno zwartych, jak i ciągłych. Po przełomie 1989 r. nastąpiła likwidacja nonsensów z poprzedniego okresu - zlikwidowano prohibity, wzrosła liczba gromadzonych wydawnictw obcojęzycznych. W celu doskonalenia profilu gromadzenia podjęto badania bibliometryczne, a wreszcie przeprowadzono — z sukcesem — kompleksową automatyzację wszystkich procesów bibliotecznych (system ALEPH) oraz zbudowano własny język informacyjno-wyszukiwawczy oparty na tezaurusie EuroVoc. Digitalizacja kompletu polskiej dokumentacji parlamentarnej oraz wykonywanie mikrofilmowych kopii zabezpieczających aktów prawnych występujących wyłącznie w formie cyfrowej dopełniają obrazu współczesnej Biblioteki Sejmowej.

Słowa kluczowe: biblioteka parlamentarna, Biblioteka Sejmowa, historia 


\section{THE CENTENARY OF THE SEJM LIBRARY. TRADITION AND MODERNITY}

The Sejm Library began operating in the fall of 1919. The motion of 18 Deputies of a people's party (PSL „Piast”) submitted to the Marshal of the Sejm in March 1919 is considered its articles of association. The nucleus of the Library's collection were collections of books on law and politics as well as collections of regulations from various institutions, which ceased to exist with the establishment of the Polish State (e.g., National Department of Galicia, Governorship in Lviv, Provisional Council of State, former Poznan Regency), as well as donations of private persons. During the twenty years of the interwar period the Sejm Library was directed by Henryk Kołodziejski - an economist by education, librarian and social activist by passion. Thanks to his efforts, until 1939 about 80000 volumes of thematically selected books and periodicals had been gathered. In 1931, Library and Archive of the Sejm and Senate were established. Based on the Library's structure, organizing and collecting of the permanently increasing archival resources were begun. Also, publishing as well as analytical and expert activity was conducted, realized by two departments established that year: legal and socio-economic departments. During the Second World War, the book collections were transferred to Berlin by the nazis, while periodicals and archival materials were almost totally destroyed. After the war, no more than $11-12 \%$ of the books taken out of the country were returned. Under the communist rule, thanks to librarians' efforts the theretofore applied profile of acquiring collections was maintained, although concessions had to be made for the benefit of the classic authors of Marxism and Leninism. However, a permanent exchange of parliamentary materials was maintained (also with the western states). The influx of foreign publications, both non-serial and serial publications was also significant. After the breakthrough of 1989 the nonsenses of the former period were liquidated - the prohibited books section was eliminated, the number of foreign publications increased. In order to perfect the collecting profile, bibliometric research was carried out and finally, all the library processes had been successfully comprehensively automatized (ALEPH system), as well as the Library's own information-search vocabulary was developed, based on EuroVoc thesaurus. Digitalizing the complete set of Polish parliamentary documentation and producing microfilm backup copies of legal acts solely existent in the digital form supplement the image of the modern Sejm Library.

Key words: parliamentary library, Sejm Library, history

*Dr Wojciech Kulisiewicz, Biblioteka Sejmowa, wojciech.kulisiewicz@sejm.gov.pl, https://orcid.org/0000-0002-7027-7131

\section{UWAGI WSTĘPNE}

Okrągłe rocznice powołania do życia różnych instytucji skłaniają zwykle do refleksji nad ich genezą, dziejami i stanem aktualnym. Bieg wydarzeń historycznych sprawił, że w 2019 r. przypada setna rocznica utworzenia Biblioteki Sejmowej [dalej: BS], najstarszej jednostki organizacyjnej zaangażowanej w obsługę polskich izb ustawodawczych.

Naszkicowanie zarysu jej dziejów napotyka jednak na poważne trudności, głównie z powodu braku źródeł. Archiwum Sejmu uległo niemal całkowitemu zniszczeniu w latach II wojny światowej, a informacje zawarte w materiałach publikowanych ograniczają się do niewielkich wzmianek i skromnych danych dotyczących wielkości 
i wartości zgromadzonych materiałów bibliotecznych. Pozostają nieliczne relacje dawnych pracowników, zbierane najczęściej pod koniec ich życia i czasami wzajemnie sprzeczne. Niewiele lepiej przedstawiają się źródła dla okresu powojennego, rozproszone i fragmentaryczne, a dopiero od lat dziewięćdziesiątych ubiegłego stulecia dysponujemy pełniejszą dokumentacją.

Dla celów niniejszego opracowania wydaje się zasadne dokonanie podziału historii BS na cztery okresy powiązane z ważnymi w dziejach Polski datami. Pierwszy z nich to dwudziestolecie 1919-1939 - czas powstania i względnie stabilnego rozwoju mimo meandrów historii polskiego parlamentaryzmu tej doby. Drugi okres to katastrofa II wojny światowej — dla biblioteki w sensie dosłownym — od jesieni 1939 r. niemal do końca 1944 r., w odniesieniu do którego możemy jedynie z fragmentarycznych dokumentów niemieckich odtworzyć dzieje księgozbioru, jako że biblioteka w sensie instytucjonalnym nie istniała. Okres trzeci to rządy komunistów (1944-1989), kiedy Sejm (formalnie od 1952 r.) był najwyższym organem władzy państwowej, lecz w rzeczywistości pozbawionym wszelkiej mocy decyzyjnej i odgrywającym w ustroju totalitarnym rolę fasadową, do pełnienia której ani biblioteka, ani zaplecze eksperckie nie były szczególnie potrzebne. Wreszcie okres czwarty, po 1989 r., kiedy w rezultacie demokratycznych przemian nastąpił rzeczywisty wzrost zapotrzebowania na informację służącą dyskusji politycznej i stanowieniu prawa, a centrum decyzyjne przeniosło się z gremiów partyjnych do organów przewidzianych w konstytucji, czyli także do parlamentu.

\section{W II RZECZYPOSPOLITEJ 1919-1939}

W czasie gdy w Europie powstawały biblioteki parlamentarne, Polska nie istniała jako niepodległe państwo (1795-1918), a burzliwe dzieje dziewiętnastowiecznych ciał parlamentarnych na ziemiach polskich nie sprzyjały wytworzeniu się jakiegokolwiek trwałego zaplecza wspomagającego pracę posłów. Jedynym wyjątkiem był Sejm Krajowy galicyjski (1861-1914), który dzięki autonomicznym rozwiązaniom przyjętym w monarchii Habsburgów cieszył się w swoich działaniach znacznym zakresem swobody. Sejm powoływał jako swój organ zarządzający i wykonawczy Wydział Krajowy (Landesausschüsse), do którego należało m.in. wszystko, co było potrzebne do posiedzeń sejmowych. Już w 1866 r. Sejm uchwałą utworzył Kancelarię Wydziału, w której składzie — wśród licznych agend administracyjnych — znalazł się także podręczny księgozbiór. Musiał powstać via facti, ponieważ brak o nim wzmianki w wewnętrznych przepisach poza stwierdzeniem, że dyrektor Kancelarii Wydziału ma m.in. nadzór „nad lokalnościami, sprzętami i książkami”. Tak więc mimo że założenia biblioteki w czasie organizacji Sejmu nie przewidziano — realne potrzeby posłów i urzędników kancelarii wymogły konieczność jej funkcjonowania. Księgozbiór nie był otoczony należytą opieką i prawdopodobnie nie był też dobrze zorganizowany. W grudniu 1898 r. ukraiński poseł Teofil Okuniewski, poparty przez 16 kolegów, interpelował do Wydziału Krajowego, stwierdzając, że książki w bibliotece walają się nieoprawione po podłodze, czytelni nie ma, ,tak jakby posłowie 
byli analfabetami i nigdy do książki zajrzeć nie potrzebowali" ${ }^{15}$. Pytał, czy i kiedy zostanie zorganizowana czytelnia dla posłów, a księgozbiór uporządkowany. Skargi ze strony posłów powtarzały się ${ }^{16}$, aż w końcu w budżecie Sejmu na rok 1907 pod pozycją 11. znalazło się 400 koron na bibliotekę. Jednocześnie przyjęto uchwałę: „Sejm poleca Wydziałowi Krajowemu przedłożyć na najbliższej sesji sejmowej odpowiednie wnioski względem umieszczenia swojej biblioteki, tudzież podręcznej biblioteki sejmowej w taki sposób, aby korzystanie z tych bibliotek było umożliwione posłom bez tych niedogodności i przeszkód, jakie obecnie istnieją"17.

Wobec braku dostępu do materiałów źródłowych nie wiemy, jaki był stan biblioteki u schyłku działalności Sejmu Krajowego galicyjskiego, niemniej należy pamiętać, że była to pierwsza polska biblioteka parlamentarna, a część jej księgozbioru po odzyskaniu przez Polskę niepodległości w 1918 r. zasiliła zbiory BS. Warto zaznaczyć, że również polscy posłowie do rosyjskiej Dumy, tworzący Koło Polskie, posiadali do swojej dyspozycji wydzielony księgozbiór, którego część została włączona do zbiorów bibliotecznych dopiero w $1925 \mathrm{r}$.

Za akt założycielski dla BS uważa się wniosek grupy 18 posłów z partii ludowej (PSL „Piast”) z Janem Dąbskim na czele, złożony do marszałka Sejmu w marcu 1919 r. z prośbą o ,utworzenie biblioteki sejmowej, zaopatrzenie jej w dzieła na razie najkonieczniejsze i stopniowe jej powiększanie"18. Uwzględniając ogrom zadań, jakie stały przed pierwszym Sejmem niepodległej Polski, oraz czas zgłoszenia wniosku (Sejm zebrał się 10 lutego 1919 r.), możemy przyjąć, że był on wyrazem uświadomionej potrzeby i troski ustawodawców o zorganizowanie zaplecza naukowego i dokumentacyjnego niezbędnego przy pracach legislacyjnych mających nadać kształt odradzającemu się państwu. Nie bez znaczenia było zapewne to, że kilku spośród wnioskodawców miało za sobą doświadczenie parlamentarne - czterech było wcześniej posłami na Sejm Krajowy galicyjski, a dwóch do Rady Państwa w Wiedniu. Zapewne lepiej niż parlamentarni debiutanci zdawali oni sobie sprawę z korzyści wynikających z istnienia przy parlamencie pomocniczego warsztatu naukowego w formie biblioteki.

Biblioteka pod względem organizacyjnym stanowiła część Biura Sejmu i dopóki działał Sejm Ustawodawczy, będący — jako konstytuanta — parlamentem jednoizbowym, nosiła nazwę Biblioteki Sejmu Ustawodawczego (1919-1922). Wraz z ukonstytuowaniem się w końcu 1922 r. oddzielnych izb Sejmu i Senatu dotychczasowe Biuro Sejmu zostało przekształcone w Biuro Sejmu i Senatu, a Biblioteka Sejmu Ustawodawczego w Bibliotekę Sejmu i Senatu. Trzy jednostki organizacyjne Biura

${ }^{15}$ Sejm Krajowy galicyjski. Sprawozdanie stenograficzne z rozpraw galicyjskiego Sejmu Krajowego 1898/9, Lwów 1899, s. 27-28.

${ }^{16}$ Sejm Krajowy galicyjski. Sprawozdanie stenograficzne z rozpraw galicyjskiego Sejmu Krajowego 1907, Lwów 1907, s. 2647.

${ }^{17}$ Ibidem, s. 1323-1324.

${ }^{18}$ Sejm Ustawodawczy II RP. Wniosek posła Jana Dąbskiego i tow. z klubu PSL „Piastowców” w sprawie utworzenia bibljoteki Sejmowej, druk nr 229, marzec 1919 r. 
Sejmu i Senatu (biuro stenograficzne, dział finansowo-gospodarczy oraz biblioteka) pracowały na rzecz obu izb, a każda z izb posiadała własną kancelarię. W 1928 r. dokonano rozdziału tak zorganizowanego biura, tworząc dwie samodzielne i niezależne jednostki, przy zachowaniu wspólnego użytkowania biblioteki przez członków i personel obu izb. Biblioteka była finansowana z budżetu Sejmu.

Na początku lat trzydziestych, po 12 latach funkcjonowania Sejmu, powstała konieczność uporządkowania narastającego zasobu archiwalnego, który obejmował zarówno dokumentację prac parlamentu, głównie dotyczącą procesu legislacyjnego, jak i akta administracyjne wytwarzane przez biura. Wykorzystano w tym celu struktury biblioteki. We wrześniu 1931 r. marszałek Sejmu wydał w formie zarządzenia statut organizacyjny Biura Sejmu Rzeczypospolitej, którym rozszerzono dotychczasowy zakres działania biblioteki, tworząc Bibliotekę i Archiwum Sejmu i Senatu. Statut jako podstawa funkcjonowania biblioteki obowiązywał do wybuchu II wojny światowej. Uznano ją za instytucję pomocniczą Sejmu i Senatu, prowadzącą w tym celu księgozbiór wszelkich wydawnictw dotyczących zakresu prac Sejmu i Senatu, ze szczególnym uwzględnieniem wydawnictw z dziedziny nauk społecznych, prawnych i ekonomicznych. Biblioteka miała udzielać w tym zakresie informacji i materiałów, prowadzić czytelnię pism codziennych i periodycznych oraz gromadzić i przechowywać wszelkie akta i dokumenty, które powstały i powstawać miały wskutek prac Sejmu i Senatu ${ }^{19}$. Na czele Biblioteki i Archiwum Sejmu i Senatu stał dyrektor, który w sprawach administracyjnych podlegał bezpośrednio marszałkowi Sejmu, a w sprawach dotyczących księgozbioru i archiwum zlecenia służbowe otrzymywał od marszałków Sejmu i Senatu. W skład personelu Biblioteki i Archiwum Sejmu i Senatu wchodzili urzędnicy i niżsi funkcjonariusze zatrudnieni w różnych formach w ramach etatów określonych budżetem Sejmu. Marszałkowie Sejmu i Senatu mieli wydać specjalny regulamin będący szczegółową podstawą funkcjonowania biblioteki ${ }^{20}$. Analogiczne przepisy, $\mathrm{z}$ wyjątkiem ustępu dotyczącego personelu biblioteki, wydał marszałek Senatu ${ }^{21}$. Wiemy z relacji świadków, że wydany został specjalny regulamin, ale po wojnie nie udało się go odnaleźć.

Początki księgozbioru BS - wobec zupełnego braku dokumentów archiwalnych — nie są łatwe do ustalenia. Wydaje się, że pierwsze książki pochodziły z księgozbioru gromadzonego przez Henryka Kołodziejskiego na potrzeby Komisji Sejmowo-Konstytucyjnej Tymczasowej Rady Stanu (organu istniejącego w 1917 r., którego zadaniem było przygotowanie zrębów polskiej państwowości) i w liczbie około 3 tys. woluminów trafiły do Sejmu. Biblioteka przejmowała, najczęściej we fragmentach, księgozbiory kilku likwidowanych instytucji, które reprezentowały interesy polskie wobec państw zaborczych albo nie miały żadnych następców prawnych. I tak przejęto część księgozbioru byłej Rejencji Poznańskiej, jak też zbiór dzienników urzędowych ze wspomnia-

19 Zarządzenie Marszałka Sejmu z dnia 29 września 1931 r. - Statut Organizacyjny Biura Sejmu Rzeczypospolitej, MP z 1931 r. nr 234, poz. 318.

20 Ibidem, $\S 13$ i $§ 14$.

${ }^{21}$ Zarządzenie Marszałka Senatu z dnia 29 września 1931 r. — Statut Organizacyjny Biura Senatu Rzeczypospolitej, MP z 1931 r. nr 234, poz. 319. 
nej wcześniej biblioteki Wydziału Krajowego we Lwowie. Inne dzieła z tego zbioru wywołały nawet spór w Sejmie, który w głosowaniu zdecydował, aby pozostawić je Uniwersytetowi Lwowskiemu ${ }^{22}$. Ze Lwowa wiosną 1924 r. sprowadzono również kilkanaście tysięcy tomów po bibliotece byłego Namiestnictwa (tj. urzędu reprezentującego cesarza Austrii w Galicji). W źródłach pojawia się także informacja o przejęciu niewielkiej partii książek z biblioteki byłego Ministerstwa ds. Galicji w Wiedniu. Wreszcie jesienią 1925 r. odzyskano księgozbiór Koła Polskiego w byłej rosyjskiej Dumie. Sporo pozycji przybyło z dubletów bibliotek warszawskich, przede wszystkim Biblioteki Publicznej Miasta st. Warszawy oraz biblioteki Wyższej Szkoły Handlowej. Bibliotekę zasilały również dary osób prywatnych, jak księgozbiór po zmarlym pośle Henryku Radziszewskim (800 dzieł), dary posła Tadeusza Regera, senatorów Władysława Jabłonowskiego, Stanisława Rosnera i innych.

Intensywne działania zmierzające do powiększenia wpływu materiałów bibliotecznych szybko przyniosły rezultaty. Uzyskano przyznanie bibliotece egzemplarza obowiązkowego druków urzędowych, a na zwołanej z inicjatywy jej dyrektora naradzie księgarzy wydawców podjęto uchwałę o nieodpłatnym przekazywaniu jednego egzemplarza ukazującego się ich nakładem dzieła o tematyce odpowiadającej profilowi zbiorów. Mimo że z realizacją uchwały bywało różnie, szczególnie w przypadku książek niskonakładowych i kosztownych, to jednak w budżecie biblioteki można było poczynić oszczędności, które przeznaczano zwłaszcza na zakup pozycji obcojęzycznych ${ }^{23}$.

Biblioteka Sejmu i Senatu rozwijała zresztą współpracę międzynarodową na zasadzie wymiany. Po ratyfikowaniu przez Polskę konwencji brukselskiej z 15 marca $1886 \mathrm{r}^{24}$ otrzymywała i wysyłała do wielu parlamentów podstawowe materiały parlamentarne (druki i sprawozdania stenograficzne). Do wzbogacenia tej współpracy przyczyniło się także powołanie w 1925 r. przy bibliotece redakcji wydawnictwa Exposé sommaire des Travaux législatifs de la Diète et du Sénat Polonais, zawierającego przethumaczone na język francuski pełne teksty lub streszczenia polskich aktów ustawodawczych. Wydawnictwo powstałe z inicjatywy marszałka Sejmu Macieja Rataja ułatwiało przełamanie bariery językowej i było chętnie przyjmowane oraz wysoko oceniane przez partnerów zagranicznych. Wypada dodać, że w redakcji zasiadali wybitni prawnicy, a sekretarzował jej dyrektor biblioteki. Do 1939 r. ukazało się siedem tomów obejmujących okres od listopada 1918 do sierpnia 1937 r. Obok dokumentów parlamentarnych gromadzono dzienniki publikacyjne wielu państw. W odniesieniu do byłych państw zaborczych (Austrii, Prus i Rosji) oraz niektórych państw zachodnioeuropejskich (Belgii, Francji, Wielkiej Brytanii) dysponowano zbiorami historycznymi sięgającymi początków XIX stulecia. Biblioteka była również depozytariuszem na Polskę wydawnictw Ligi

${ }^{22}$ Sejm II RP, okres I. Sprawozdanie stenograficzne z 32. posiedzenia Sejmu Rzeczypospolitej z dn. 12 kwietnia 1923 r., 1. 6-7.

${ }^{23}$ J. Kramm, Henryk Kolodziejski jako bibliotekarz: wspomnienie, „Przegląd Biblioteczny” 1955, z. 2 , s. 158 .

${ }^{24}$ Konwencja między Szwajcarją, Belgją, Brazylją [...] dotycząca wymiany międzynarodowej druków urzędowych oraz publikacji naukowych i literackich (z 15 marca 1886 r.), MP z 1921 r. nr 151. 
Narodów i Fundacji Carnegiego. Otrzymywała ona wydawnictwa Międzynarodowego Biura Pracy, Międzynarodowego Instytutu Rolnictwa, Międzynarodowego Instytutu Handlu i wielu innych organizacji. Kolekcję wzbogacały zbiór traktatów Martensa (1494-1926), zbiór dokumentów dyplomatycznych Francji (tzw. Żółta Księga 1856-1923) oraz zbiór dokumentów dyplomatycznych Rzeszy Niemieckiej (Die Große Politik der Europäischen Kabinette 1871-1914).

Od samego początku w działaniu Biblioteki Sejmu i Senatu przestrzegano założonego profilu gromadzenia zbiorów. Obok norm prawnych i wydawnictw oficjalnych gromadzono książki z zakresu prawa, ze szczególnym uwzględnieniem prawa konstytucyjnego czy raczej publicznego, a także ekonomii, polityki, nauk społecznych i historii najnowszej. Szczególny nacisk kładziono także na doktryny polityczne oraz historie partii i ruchów politycznych. Specyficzna w skali europejskiej i obszerna była kolekcja poświęcona bolszewizmowi, licząca w połowie lat dwudziestych ponad 900 tytułów. Według danych z 1927 r. księgozbiór liczył około 16 tys. dzieł w 35 tys. woluminów, a bieżący wpływ periodyków wynosił 473 wydawnictwa w języku polskim oraz $309 \mathrm{w}$ językach obcych ${ }^{25}$. Ostatnie wydane przed wybuchem wojny dokumenty informują, że księgozbiór Biblioteki Sejmu i Senatu w dniu 15 grudnia 1938 r. liczył 36928 tytułów dzieł w blisko 48 tys. woluminów oraz 3025 tytułów czasopism w około 30 tys. woluminów ${ }^{26}$. Zasób ten stawiał Biblioteki Sejmu i Senatu w rzędzie średnich w skali europejskiej, ale ze względu na specjalizację i bogactwo wydawnictw urzędowych, w tym parlamentarnych, czynił z niej jedną z bibliotek najlepiej przygotowanych do wypełniania swoich zadań.

W pierwszym roku istnienia Biblioteka Sejmu i Senatu nie posiadała pomieszczeń umożliwiających uruchomienie czytelni i podjęcie prac nad porządkowaniem i opracowaniem napływających materiałów. Pod koniec 1920 r. uzyskała dwa pokoje położone nieopodal sali obrad, co pozwoliło na uruchomienie najpotrzebniejszej czytelni prasy i dokumentów urzędowych oraz podjęcie opracowania zbiorów. Do 1929 r. przeprowadzono kilka uciążliwych przeprowadzek w obrębie gmachu sejmowego. Spowodowane one były zmieniającą się podczas kadencji konfiguracją klubów sejmowych. Mnożenie tych często efemerycznych bytów zawsze wywoływało wstrząsy na parlamentarnym zapleczu, a nonsensowne zmiany przydziału pomieszczeń wymagały znacznego wysiłku pracowników sejmowych biur. Wreszcie po oddaniu do użytku w 1928 r. nowej sali posiedzeń oraz gmachu hotelu dla posłów i senatorów biblioteka uzyskała stosowne pomieszczenia. Czytelnia główna pozostała w starym budynku, natomiast czytelnię czasopism, magazyny zasobowe, wyposażone w nowoczesne regały i zabezpieczone przeciwpożarowo, zlokalizowano w nowym gmachu. Zmiany te pozwoliły na pełne zaspokojenie potrzeb czytelników ${ }^{27}$ oraz — jak można przypuszczać — umożliwiły

${ }^{25}$ Parlament Rzeczypospolitej Polskiej 1919-1927, red. H. Mościcki, W. Dzwonkowski, Warszawa 1928, s. 58.

${ }^{26}$ Sejm II RP, kadencja V. Sprawozdanie Komisji Budżetowej o preliminarzach budżetowych Sejmu (część 2a.) i Senatu (część 2b) na rok 1939/40, druk nr 100, cz. 2a i 2b, luty 1939 r.

27 J. Kramm, Henryk Kotodziejski.., s. 159. 
rozszerzenie zakresu działania biblioteki o funkcje archiwalne. Warto wspomnieć, że również wówczas w okrągłej sali obrad Komisji Budżetowej umieszczono niewielki, ale starannie dobrany i opracowany księgozbiór podręczny, zawierający materiały porównawcze z teorii i praktyki prawa budżetowego innych państw. Sala ta jest dzisiaj czytelnią główną Biblioteki Sejmowej.

W okresie dwudziestolecia międzywojennego rozwijała się obsada personalna Biblioteki. Początkowo obok kierownika, a wkrótce dyrektora Henryka Kołodziejskiego zatrudniona była tylko jedna wykwalifikowana bibliotekarka oraz goniec. Pod koniec 1921 r. zatrudnionych było już sześć osób, w 1928 r. — 13, a do 1939 r. liczba ta wzrosła do 20 pracowników. Personel był okresowo wspomagany przez dwie lub trzy osoby odbywające praktykę biblioteczną, wsparcia udzielały również wolontariuszki.

Od początku istnienia biblioteki aż do 1939 r. kierował nią Henryk Kołodziejski — z wykształcenia ekonomista, z zamiłowania bibliotekarz, a przy tym działacz społeczny i członek loży masońskiej. Karierę biblioteczną rozpoczął w 1915 r. w Bibliotece Publicznej Miasta st. Warszawy, gdzie pełnił obowiązki kierownika działu bibliografii. Dwa lata później zajął się gromadzeniem wspomnianego już księgozbioru na potrzeby Komisji Sejmowo-Konstytucyjnej Tymczasowej Rady Stanu mającej opracować projekt przyszłej konstytucji i ordynacji wyborczej do Sejmu. Książki te — jak już wspomniano — były zaczątkiem zbiorów BS. Szybki rozwój, zarówno ilościowy, jak i jakościowy zawdzięczała ona w wysokim stopniu wiedzy, energii i determinacji w działaniu swego dyrektora. Kołodziejski tworzył projekty usprawnienia prac bibliotecznych i doskonalenia środków szybkiego, wyczerpującego informowania użytkowników. Zakładając katalog działowy, odrzucił system klasyfikacji dziesiętnej, który uważał za zbyt sformalizowany i nieodpowiedni dla biblioteki parlamentarnej. Przemyślał natomiast i opracował schemat katalogu obejmujący trzy główne dziedziny: prawo, nauki społeczno-gospodarcze i historyczno-polityczne. Składał się on z 24 działów i przeszło 300 poddziałów oznaczonych sygnaturami cyfrowymi i literowymi. Katalog druków zwartych uzupełniały odsyłacze do specjalnego katalogu periodyków oraz dokumentów w formie opisów ważniejszych wydarzeń odnotowanych przez prasę krajową i zagraniczną. Kołodziejski osobiście czuwał nad prawidłową klasyfikacją materiałów i rozszerzaniem ram katalogu, w miarę jak nowe zagadnienia znajdowały swój wyraz w piśmiennictwie.

Na przełomie lat dwudziestych i trzydziestych do prac pomocniczych nad projektami ustaw, uzasadnieniem wniosków i przygotowaniem wystąpień merytorycznych, w bibliotece powołano dwa zespoły (referaty): prawny i społeczno-gospodarczy. Pracownicy biblioteki mieli obowiązek zbierania danych statystycznych, opracowywania zestawień porównawczych, sporządzania wyciągów budżetowych i wykonywania innych prac zlecanych przez posłów lub senatorów w uzgodnieniu z dyrektorem. Posłowie wysoko oceniali pracę informacyjną biblioteki, o czym świadczy sprawozdanie Komisji Budżetowej o preliminarzach Sejmu i Senatu ze stycznia 1930 r.: ,personel jej wykonuje pracę, która wykracza znacznie poza zakres prac bibliotecznych: wyszukuje i przygotowuje materiały i dane na życzenie posłów, dokonuje zawiłych nieraz obliczeń statystycznych, udziela różnych informacji, zwłaszcza z zakresu obcego ustawodawstwa [...]. Oczywiście jest to 
dopiero skromny zaczątek przyszłego «Biura prac przygotowawczych dla posłów i senatorów», które z czasem - mam nadzieję — powstanie przy Bibliotece naszej. Obecnie mamy już zawiązek takiego biura w postaci Referatu Prawnego przy Bibliotece, który powinien być najprędzej uzupełniony przez referat «statystyczno-ekonomiczny». Referat Prawny w ubiegłym roku — poza normalną funkcją informacyjną — zgromadził i zestawił [...] cały materiał dotyczący precedensów i wypadków, mających znaczenie proceduralne. W ten sposób zapoczątkowane zostało porządkowanie polskiego obyczajowego prawa parlamentarnego. Te dokonujące się stopniowo przekształcenia Biblioteki Sejmu i Senatu na pomocniczy aparat pracy parlamentu uważać należy za słuszne, a nawet niezbędne"28. Jak wynika z cytowanej wypowiedzi, już w 1930 r. myślano — zapewne nie bez inspiracji ze strony dyrektora Kołodziejskiego — nad przekształceniem biblioteki w kierunku dzisiejszych parlamentarnych biur eksperckich. Bieg wydarzeń historycznych sprawił, że na pełną realizację tego pomysłu zabrakło czasu.

Zgodnie z regulaminem biblioteki wypożyczać materiały z jej zasobów oraz korzystać z nich w czytelniach mogli przede wszystkim posłowie i senatorowie, a ponadto pracownicy biur Sejmu i Senatu, dziennikarze członkowie Klubu Sprawozdawców Parlamentarnych, upoważnieni urzędnicy ministerstw i urzędów centralnych, pracownicy naukowi, a nawet studenci skierowani przez władze uczelni i — pod pewnymi warunkami — zwykli ludzie z ulicy. W materiałach źródłowych są wzmianki o otwartości i przyjaznym stosunku pracowników biblioteki do użytkowników: „Każdy mógł w razie potrzeby zasięgnąć [...] porady naukowej czy wskazówek bibliograficznych u dyrektora Kołodziejskiego, który mimo pochłaniających go różnorodnych spraw publicznych — nie szczędził czasu i życzliwej pomocy. Toteż pokój dyrektora bywał formalnie oblegany przez osoby, które częstokroć nadużywały jego wielkiej uczynności"29.

Jak wspomniano, biblioteka prowadziła dwie czytelnie: główną i czasopism, obie zlokalizowane w kompleksie gmachów sejmowych. Utrwalił się kontynuowany i dzisiaj zwyczaj pracy w dni posiedzeń plenarnych do zakończenia obrad. Frekwencja posłów powoli, acz systematycznie rosła. Wiemy, że mimo zredukowania liczby posłów i senatorów na mocy autorytarnej konstytucji z kwietnia 1935 r. o 46\%, spadek frekwencji w czytelniach wyniósł tylko $21 \%$. Podobnie liczba wypożyczeń z magazynów (a więc bez księgozbiorów podręcznych) wynosiła w 1935 r. — 517, a w 1936 r. 522 (dane dotyczą tylko posłów i senatorów). W latach trzydziestych szybko wzrastała także frekwencja użytkowników spoza parlamentu. W 1933 r. odnotowano 750 osób miesięcznie, w 1935 r. — 900, a w 1937 r. — 1050 osób miesięcznie ${ }^{30}$.

Wchodząc w dwudziesty rok istnienia, Biblioteka i Archiwum Sejmu i Senatu stanowiły mocny i dynamiczny ośrodek informacji naukowej w zakresie prawa i polityki, dobrze przystosowany do pełnienia wyznaczonych zadań i stale doskonalący

${ }^{28}$ Sejm II RP, okres II. Sprawozdanie Komisji Budżetowej o preliminarzach budżetowych Sejmu i Senatu na rok budżetowy 1930/31, druk nr 700, cz. 2a i 2b, styczeń 1930 r.

29 J. Kramm, Henryk Kolodziejski..., s. 160.

${ }^{30}$ Sejm II RP, kadencja IV. Sprawozdanie Komisji Budżetowej o preliminarzach budżetowych Sejmu (część 2a) i Senatu (część 2b) na rok 1937/38, druk nr 300, cz. 2a i 2b, luty 1937 r. 
metody pracy na potrzeby parlamentu. Biblioteka cieszyła się opinią poważnej placówki informacyjno-naukowej w kraju, a zarazem jednej z najlepiej prowadzonych bibliotek warszawskich. Wybuch wojny w 1939 r. położył kres jej istnieniu.

\section{KATASTROFA LAT WOJNY I OKUPACJI}

W czasie działań wojennych we wrześniu 1939 r. gmach Sejmu został w większej części zniszczony (m.in. sala posiedzeń i przyległy budynek z czytelnią główną, katalogami oraz inwentarzami biblioteki), ocalała natomiast czytelnia czasopism i większość magazynów zlokalizowanych w nowoczesnym budynku o żelbetowych stropach. Najniższe kondygnacje mieszczące archiwalia zostały zalane wodą, pochodzącą prawdopodobnie z akcji gaszenia pożaru na wyższych piętrach. Dopóki w pierwszych dniach września istniała możliwość dostępu do gmachu, dyrektor H. Kołodziejski i pracownicy zbierali się codziennie, aby podejmować działania zmierzające do zabezpieczenia zbiorów. Między innymi wywieziono wówczas na wschód część najcenniejszych akt archiwalnych. Przetrwały one wojnę i w 1956 r. zostały zwrócone przez władze rosyjskie. Po kapitulacji Warszawy podjęto próbę przeniesienia zbiorów bibliotecznych do położonego nieopodal i niezniszczonego gmachu Izby Przemysłowo-Handlowej, ale prace te zostały przerwane przez Niemców, którzy ponadto odmówili pracownikom biblioteki wstępu do ocalałych budynków sejmowych. Gdy tych samych pracowników zatrudniono w lutym 1940 r. do porządkowania zalanych wodą archiwaliów Sejmu, stwierdzili oni, że księgozbiór zniknął, ale kiedy i dokąd został wywieziony, wówczas nie udało im się ustalić. Ocalałe materiały archiwalne przeniesiono do wyznaczonej przez hitlerowców centralnej składnicy, gdzie spłonęły w listopadzie 1944 r. Warto dodać, że w trakcie trwających około siedmiu miesięcy prac porządkowych starano się część materiałów (szczególnie personalnych) skutecznie „wyłączyć” ze zbioru, aby uniemożliwić ich ewentualne wykorzystanie przez Gestapo.

Odtworzenie dziejów księgozbioru BS po wrześniu 1939 r. napotyka na poważne trudności ze względu na fragmentaryczność lub brak dostępu do źródeł archiwalnych. Niemniej dzięki pracom Andrzeja Mężyńskiego możemy przynajmniej częściowo prześledzić losy książek w latach wojny ${ }^{31}$.

Już w czasie działań wojennych 23 września 1939 r. szef SS Heinrich Himmler polecił Wydziałowi II Głównego Urzędu Bezpieczeństwa Rzeszy (Reichssicherheitshauptamt, dalej: RSHA) zorganizowanie jednostki, której zadaniem miało być „zabezpieczenie prehistorycznych materiałów wykopaliskowych i prehistorycznych zabytków w Polsce", nazywanej też przez samych esesmanów oddziałem operacyjnym do zabezpieczenia wartości naukowych i sztuk pięknych, a najczęściej określanym jako Kommando Paulsena — od nazwiska dowódcy, profesora prehistorii Uniwersytetu Berlińskiego, a jednocześnie Untersturmführera SS Petera Paulsena. Przed

${ }^{31}$ A. Mężyńnki, Okupacyjne dzieje księgozbioru Biblioteki Sejmowej, „Przegląd Sejmowy” 1994, nr 4; idem, Kommando Paulsen: październik-grudzień 1939 r. Warszawa 1994; idem, Kommando Paulsen: Organisierter Raub polnischer Kulturgüter während des Zweiten Weltkrieges, Köln 2000. 
pierwszą wyprawą do Polski szef Wydziału II RSHA Standartenführer SS Alfred Franz Six, z wykształcenia filozof, polecił Paulsenowi ,zabezpieczenie wszystkich dóbr kulturalnych w Polsce, które mają jakąkolwiek wartość i znaczenie dla problematyki germańskiej i niemieckiej oraz sprowadzenie z tych zasobów do Rzeszy tylu przedmiotów, ile tylko będzie możliwe" "32. Tak więc krąg zainteresowań Kommanda uległ rozszerzeniu - były to już nie tylko wykopaliska i prehistoria, ale praktycznie wszystkie dzieła sztuki. Warto zaznaczyć, że z pierwszej podróży do Polski (1-14 października 1939 r.) Paulsen przywiózł do Berlina łup nie byle jaki, bo odnaleziony w podziemiach katedry w Sandomierzu Ołtarz Mariacki, dzieło rzeźbiarza pochodzącego z Norymbergi, a więc w rozumieniu speców z SS — niemieckie.

W tym czasie wśród decydentów Wydziału II RSHA musiała pojawić się idea zorganizowania własnej biblioteki, aby stworzyć zaplecze informacyjne dla prowadzonych przez ten wydział prac, odpowiednio do określenia zawartego $\mathrm{w}$ jego nazwie: badania światopoglądowe i ocena. Podstawę tej biblioteki miały stanowić księgozbiory „polityczne" zwiezione z krajów podbitych i zarekwirowane w samej Rzeszy. Działania Paulsena w Polsce potwierdzają taką hipotezę, ponieważ - mimo że odwiedzał on wielkie biblioteki warszawskie i krakowskie - to spakował i wywiózł do Berlina kilka skromniejszych rozmiarami bibliotek „,politycznych”, m.in. księgozbiory działających w Warszawie instytutów (węgierskiego, duńskiego, francuskiego), Instytutu Żydowskiego, Instytutu Ukraińskiego, Instytutu Współpracy z Zagranicą. Realizował w ten sposób instrukcje Wydziału II RSHA, aby wywozić biblioteki „kościelno-polityczne, marksistowskie, żydowskie lub masońskie, pod względem językowym — polskie, niemieckie, francuskie, angielskie". Największym i najcenniejszym łupem Paulsena był księgozbiór BS. Decyzja o wywozie zasobu biblioteki zapadła w pierwszej połowie listopada $1939 \mathrm{r}$. Pierwsze trzy ciężarówki (w tym dwie z przyczepami), należące do firmy przewozowej Richarda Schultzego dotarły do Berlina 17, 18 i 23 listopada. Następnie wysłano jeszcze cztery wagony towarowe, z których ostatni dojechał do Berlina 2 grudnia. Te dane pochodzące z dokumentów niemieckich pozwalają przypuszczać, że wywieziono cały ocalały księgozbiór, czyli około 48 tys. woluminów. Zbiór gazet i czasopism został częściowo spalony w ogrodzie sejmowym, a częściowo trafił na przemiał do podwarszawskiej papierni. W 1940 r. zdemontowano i wywieziono metalowe regały, co było częstą praktyką Niemców w okupowanych krajach.

W Berlinie książki trafiły do siedziby Wydziału II RSHA przy Eisenacher Straße 12. Można wspomnieć, że był to dawny budynek Wielkiej Loży Wolnomularstwa Niemiec (Große Landesloge der Freimaurer von Deutschland). Złożone w piwnicach i w jednej z sal (nr 18) były poddawane niespiesznemu porządkowaniu przez jednego pracownika, niejakiego Joachimskiego. Księgozbiór pozostawał w dyspozycji szefa Wydziału II, wspomnianego już A.F. Sixa, który prawdopodobnie wydał polecenie jego skatalogowania. W $1941 \mathrm{r}$. Wydział VII RSHA (tak oznaczano po 1 stycznia 1941 r. dawny Wydział II) przystąpił do organizacji własnej biblioteki. Wiosną 1942 r.

32 A. Mężyński, Okupacyjne dzieje..., s. 192. 
było w niej zatrudnionych blisko 25 osób, a zbiory dzieliły się na trzy grupy: „Rzesza Niemiecka i generalia”, „Przeciwnik” i „Zagranica”. Nie wiemy, ile książek z BS włączono do zasobu tej nowo utworzonej biblioteki, ile przekazano jako dublety, a ile uznano za nieprzydatne. Na nielicznych egzemplarzach, które po wojnie wróciły do Warszawy, widnieją sygnatury „Ausl” (Zagranica) lub „Ml” (Rzesza Niemiecka i generalia), nadawane według nie do końca jasnych kryteriów.

W nieokreślonym bliżej czasie część księgozbioru pochodzącego z BS została wywieziona z Berlina i ukryta przed alianckimi bombami na zamku Houska w czeskich Sudetach. Można postawić hipotezę, że były to książki, które weszły do zasobu biblioteki RSHA i zostały skatalogowane. W sierpniu 1945 r. polski minister spraw zagranicznych poinformował prezydenta Krajowej Rady Narodowej z nieco przesadnym optymizmem o odnalezieniu w Czechach „biblioteki Sejmu i Senatu RP”. W lutym 1946 r. została zawarta umowa rewindykacyjna między Czechosłowacją i Polską, na mocy której od marca tegoż roku zaczęły napływać transporty m.in. z odnalezionymi zbiorami bibliotecznymi. W raportach agend rządowych jest mowa o 38 tys. woluminów z „różnych bibliotek, głównie Sejmu i Senatu”. Do gmachu Sejmu w grudniu 1946 r. dotarło 176 skrzyń z książkami przywiezionymi w dwóch wagonach kolejowych z Pragi. Do końca roku rozpakowano 115 skrzyń zawierających 10109 woluminów, z czego tylko 3340 było własnością BS. W piśmie z 10 marca 1948 r. skierowanym do Naczelnej Dyrekcji Bibliotek (przy Ministerstwie Oświaty) dyrektor BS Zofia Hryniewicz podała, że z Czechosłowacji rewindykowano w pierwszym transporcie 3477 woluminów (a więc liczbę zbliżoną do podanej wyżej), a w drugim — 4820, co w sumie dawało 8297 woluminów (kopia maszynopisu w zbiorach BS) z księgozbioru wywiezionego przez Kommando Paulsena jesienią 1939 r., czyli około 17,3\%. Jeszcze inne dane zawiera pismo tej samej dyrektor BS z 15 marca 1950 r. skierowane do Biura Rewindykacji przy Ministerstwie Handlu Zagranicznego w odpowiedzi na pytanie o wartość rewindykowanych książek. Stwierdza ona, że w 100 skrzyniach otrzymano 10405 woluminów, z czego 6627 pochodziło z Biblioteki Sejmu i Senatu. Z tej liczby do zasobu włączono 5230 woluminów (kopia maszynopisu w zbiorach BS), czyli niecałe $11 \%$ utraconego księgozbioru.

Być może nie wszystkie przywiezione z Czechosłowacji woluminy trafiły do BS, ale jednocześnie nie ujawniono dotąd, aby w jakiejkolwiek polskiej bibliotece znajdowała się większa partia książek ze znakami własnościowymi przedwojennej biblioteki parlamentarnej. Wiadomo też, że Niemcy nie wywieźli w Sudety wszystkich zagarniętych w 1939 r. książek. Budynek RSHA przy Eisenacher Straße 12 przetrwał bombardowania i szturm Berlina w stanie na tyle dobrym, że został zajęty na użytek amerykańskiej armii okupacyjnej ${ }^{33}$. Książki złożone w piwnicach ocalały — w lipcu 1945 r. ich liczbę oceniano na 50-60 tys. woluminów. Amerykański komendant zarządził, aby „biblioteki, które można zidentyfikować, zwrócić ich prawowitym

${ }^{33}$ S. Kubina, Die Bibliothek des Berliner Rätekommunisten Alfred Weiland (1906-1978), Köln 1949, s. 19. 
właścicielom". Zajęła się tym cywilna administracja niemiecka, która w sprawozdaniu z lutego 1946 r. podała, że ,zarządzono odtransportowanie bibliotek biskupowi, najwyższej radzie kościelnej, wspólnocie żydowskiej i loży. Gdy prowadzono te prace, amerykański komendant zamknął cały budynek i zabronił zabierania kolejnych przedmiotów"34. O zbiorach sejmowych nie wspomniano. $\mathrm{Z}$ dużym prawdopodobieństwem można wyrazić pogląd, że uległy one rozproszeniu. Kilka woluminów odnaleziono w księgozbiorze A. Weilanda, niemieckiego komunisty, który od czerwca 1945 r. do lutego 1946 r. zajmował się przeglądaniem i sortowaniem książek RSHA. Część przekazano jeszcze w latach wojny innym bibliotekom niemieckim jako dublety, część mogła ulec zniszczeniu wskutek złych warunków przechowywania. Mimo prowadzonych poszukiwań nie udało się dotąd ustalić, czy większy zbiór książek z BS trafił po wojnie do jednej z bibliotek niemieckich.

\section{BIBLIOTEKA SEJMOWA W OKRESIE RZACDÓW KOMUNISTYCZNYCH 1944-1989}

Wobec prawie całkowitego zniszczenia biblioteki przez Niemców powojenną odbudowę zaczynano od podstaw. Już przy Krajowej Radzie Narodowej quasi-reprezentacji społeczeństwa uchwalającej ustawy, powołanej w czasie okupacji przez komunistów, istniał księgozbiór, o którym wiemy, że zaczął powstawać jesienią 1944 r. w Lublinie, a następnie został przeniesiony do Warszawy, gdzie jako Biblioteka Krajowej Rady Narodowej stanowił jeden z wydziałów Biura Prezydialnego KRN. Status biblioteki został określony aktem niskiego rzędu, bo okólnikiem dyrektora Biura Prezydialnego KRN z grudnia 1945 r. Po otwarciu Sejmu Ustawodawczego w lutym 1947 r. uruchomiono również bibliotekę. Zwyczajowo nazywano ją Biblioteką Sejmową, jako że w 1946 r. w sfałszowanym przez komunistów referendum zlikwidowano formalnie Senat i parlament do 1989 r. pozostawał jednoizbowy. Statut organizacyjny Kancelarii Sejmu Ustawodawczego nadany 11 września 1948 r. przez marszałka Sejmu usankcjonował nazwę biblioteki, a jednocześnie potraktował ją jako jedno z sześciu biur Kancelarii podlegających szefowi Kancelarii Sejmu, a nie jako jednostkę podległą — jak w okresie międzywojennym — bezpośrednio marszałkowi izby.

Po uchwaleniu stalinowskiej konstytucji (z 22 lipca 1952 r.) połączono dotychczas odrębne kancelarie Rady Państwa i Sejmu, a - mimo że formalnie Sejm stał się najwyższym organem władzy państwowej - nowo powstały organ nazwano Kancelarią Rady Państwa. W jej ramach organizacyjnych znalazła się, wśród licznych biur, również biblioteka. Zgodnie z tymczasowym statutem organizacyjnym Kancelarii Rady Państwa, BS miała składać się z samodzielnych referatów: ogólnego, uzupełniania księgozbioru, opracowania księgozbioru, czytelni i biblioteki podręcznej ${ }^{35}$. Charakterystyczne, że biblioteka była wówczas jedyną jednostką organizacyjną, która zachowała w nazwie przymiotnik ,sejmowy”.

\footnotetext{
${ }^{34}$ Ibidem, s. 21.

${ }^{35}$ Uchwała Rady Państwa z dnia 5 sierpnia 1952 r. w sprawie połączenia Kancelarii Rady Państwa z Kancelarią Sejmu Ustawodawczego, M.P. z 1952 r. nr 73, poz. 1158, § 12, ust. 2.
} 
Po częściowej likwidacji stalinizmu — w ramach tak zwanej odwilży po październiku 1956 r. — przywrócono oddzielną Kancelarię Sejmu, w której składzie znalazła się i BS. Zmiany organizacyjne traktowano jako jeden z przejawów wzrostu roli i większej samodzielności parlamentu w zmodyfikowanym systemie. W okresie późniejszym nie zmieniano już organizacyjnego usytuowania biblioteki. Pozostaje ona wewnętrzną jednostką Kancelarii Sejmu i jest finansowana z jej budżetu. Oczywiście nie oznacza to, że organizacja samej BS i jej pozycja w stosunku do innych bibliotek polskich nie ulegały zmianom.

Jedną z tendencji charakterystycznych dla okresu rządów komunistów była — jak wiadomo - centralizacja. Skrajnie scentralizowany aparat administracyjny dążył do analogicznego zorganizowania wszystkich dziedzin życia społecznego, z nauką i kulturą włącznie. Od końca lat czterdziestych pojawiały się sugestie, aby biblioteka wzięła na siebie rolę administracyjnej centrali bibliotek urzędowych. Sami zainteresowani, czyli bibliotekarze, robili wszystko, aby uniknąć wprowadzenia tych pomysłów w życie ${ }^{36}$. W 1951 r. Centralny Zarząd Bibliotek zaproponował — z poparciem samego Prezydium Rady Ministrów - aby BS objęła nadzór i opiekę instrukcyjną nad bibliotekami Wojewódzkich Rad Narodowych. Jeszcze w 1953 r. dyrektor BS przyrzekała, że „,będzie dążyć do zrealizowania propozycji [...] Centralnego Zarządu Bibliotek"37, ale nie podjęto żadnych działań w tym kierunku. W odniesieniu do BS wielokrotnie używano określeń: „centralna”, „specjalistyczna”, a nawet Centralna Biblioteka Legislacyjna i reprezentacyjna biblioteka państwa. Miało to służyć podniesieniu prestiżu i łatwiejszemu pozyskiwaniu środków budżetowych. W praktyce dawało to niewiele. Status BS określały kolejne statuty Kancelarii Sejmu i wydawane na ich podstawie regulaminy organizacyjne. Dla podkreślenia, że BS nie jest tylko jednym z licznych biur Kancelarii Sejmu, w kwietniu 1976 r. Prezydium Sejmu uchwałą nadało bibliotece statut. Był on mieszanką ideologicznej nowomowy w rodzaju: „Biblioteka działa [...] dla potrzeb [...] socjalistycznego wychowania społeczeństwa" i norm o charakterze porządkowym określających, na jaki okres może nastąpić wypożyczenie książek i druków. Jednocześnie sprecyzowano zadania BS i zakres gromadzonych materiałów. Miały one dotyczyć historii i teorii parlamentaryzmu, praktyki parlamentarnej, nauk politycznych i prawnych, w szczególności z zakresu prawa państwowego i prawa administracyjnego, ruchu robotniczego i nauk społecznych. BS miała również gromadzić i udostępniać materiały związane bezpośrednio z działalnością Sejmu, czyli druki i sprawozdania stenograficzne. Ponieważ na mocy uchwały Rady Ministrów z 1968 r. BS uznano za naukową, w statucie wykreowano Radę Naukową jako organ doradczy i opiniodawczy pod przewodnictwem posła. Należy dodać, że Rada ta nie przejawiała żadnej aktywności.

Kierownictwo BS już wcześniej podejmowało inicjatywy zmierzające do umocnienia jej pozycji, a przede wszystkim do zapewnienia stosownych pomieszczeń. Miało się

36 Protokół Narady Bibliotecznej zwołanej przez ob. Marszałka Sejmu Ustawodawczego RP dn. 21 października 1949 r. o godz. 13, Warszawa 1949, s. 3 (maszynopis w zbiorach BS).

37 Wytyczne pracy Biblioteki Sejmowej na rok 1953, oprac. Z. Hryniewicz, Biblioteka Sejmowa, Warszawa 1953, s. 1 (maszynopis w zbiorach BS). 
do tego przyczynić powołanie przy marszałku Sejmu komisji bibliotecznej złożonej głównie z posłów i przedstawicieli świata nauki, która stanowiłaby swoiste probiblioteczne lobby. Pierwszy wniosek w tej sprawie zgłoszono na specjalnej naradzie w sprawach bibliotecznych, która z udziałem wicemarszałka Sejmu i posłów odbyła się jesienią 1949 r. Za powołaniem takiej komisji opowiadano się również na konferencji poświęconej sprawom bibliotecznym przeprowadzonej w grudniu $1960 \mathrm{r}$. pod przewodnictwem marszałka Sejmu. Mimo zgodności pozytywnych poglądów oraz przytaczania licznych przykładów innych bibliotek parlamentarnych komisji nigdy nie powołano.

Jak już wspomniano, po katastrofie wojennej pierwszy księgozbiór BS zaczął powstawać jeszcze jesienią 1944 r. w Lublinie, gdzie tymczasową siedzibę miała Krajowa Rada Narodowa. Pierwszy kierownik Biblioteki KRN Kazimierz Zieleniewski został upoważniony przez Bolesława Bieruta do przejęcia książek o treści politycznej, społecznej i podręczno-informacyjnej ze zorganizowanego przez Niemców w Lublinie magazynu przy ul. Szopena $28^{38}$. Z tych książek wybrano później około 2 tys. woluminów do księgozbioru BS. Po przeprowadzce do Warszawy biblioteka podjęła działalność jesienią 1946 r. Z zachowanego sprawozdania za grudzień wynika, że czytelnie odwiedziło 281 osób, które wypożyczyły 473 książki. Księgozbiór liczył wówczas 17485 woluminów.

W polityce gromadzenia zbiorów starano się utrzymać kierunek wyznaczony jeszcze przed wojną przez dyrektora Kołodziejskiego, a do końca lat czterdziestych przyznawano, że „obecna Biblioteka Sejmowa pracuje w oparciu o tradycję pierwszorzędnie zorganizowanej biblioteki przedwojennej”39, chociaż były i różnice wynikające z innego ukształtowania władzy państwa, którego polityczne kierownictwo spoczywało w rękach partii komunistycznej. W miarę pogłębiania się dyktatury komunistycznej zanikały nawiązania do tradycji przedwojennej, a w polityce gromadzenia coraz większy nacisk kładziono na pozyskiwanie dzieł Marksa, Engelsa, Lenina, Stalina oraz Wyszyńskiego, Mołotowa, Żdanowa i innych. W gromadzeniu dokumentacji organizacji międzynarodowych zaczęły zaś dominować tzw. światowe federacje (związków zawodowych, młodzieży demokratycznej, kobiet, obrońców pokoju), czyli podmioty mające swym istnieniem udowadniać zasięg wpływów komunistycznych na świecie.

Do końca lat czterdziestych zgromadzono ponad 100 tys. pozycji bibliotecznych, z których około 70 tys. zakwalifikowano do zbiorów. W tej liczbie około 15 tys. stanowiły parlamentaria i wydawnictwa ONZ. Tak duży w tak krótkim czasie przyrost zasobu był prawdopodobny z powodu nietypowych sposobów gromadzenia w okresie bezpośrednio po zakończeniu wojny. Obok zakupów, darów i wymiany funkcjonowały wówczas tak zwane "przydziały” z Centralnego Zarządu Bibliotek. Były to

${ }^{38}$ Pismo Przewodniczącego Krajowej Rady Narodowej do Kierownika Resortu Pracy, Opieki Społecznej i Zdrowia z dnia 14 listopada 1944 r. (kopia maszynopisu w zbiorach BS).

${ }_{39}$ Z. Hryniewicz, Narada biblioteczna w Sejmie [21 października 1949 r.], Warszawa 1949 (maszynopis w zbiorach BS). 
książki pochodzące z bibliotek poniemieckich; pozostawione przez właścicieli ziemskich zmuszonych do opuszczenia swych domów przez reformę rolną (księgozbiory podworskie); takie, których właścicieli po wojnie nie można było ustalić; wreszcie przekazywane w wyniku likwidacji bibliotek przy państwowych jednostkach organizacyjnych lub likwidacji samych jednostek. Książki przekazywano na podstawie decyzji administracyjnych, często bez sortowania i refleksji nad ich przydatnością dla poszczególnych bibliotek. BS jako biblioteka pracująca w ramach organizacyjno-administracyjnych centralnych organów państwa była w tych przydziałach jednostką preferowaną. Stąd wynikał gwałtowny przyrost liczby posiadanych woluminów i jednocześnie konieczność stałej selekcji księgozbioru. Przejęto księgozbiór zlikwidowanego w 1949 r. Ministerstwa Ziem Odzyskanych (około 3,5 tys. woluminów), księgozbiór Prezydium Rady Ministrów z wieloma pozycjami odpowiadającymi profilowi biblioteki parlamentarnej (12 383 woluminy) i inne pomniejsze. Istniał także pochodzący z przydziałów Naczelnej Dyrekcji Bibliotek księgozbiór niemiecki, w 1953 r. oceniany na około 100 tys. książek, z których $60 \%$ zamierzano włączyć do zasobu $\mathrm{BS}^{40}$. W planie pracy na 1954 r. przewidywano dokonanie wyboru pozycji do zbiorów BS, ich dezynfekcję i częściowe opracowanie, a także przekazanie tzw. hitlerianów w jednym egzemplarzu do decyzji Centralnego Zarządu Bibliotek, wydzielenie pozycji nadających się do zbiorów innych bibliotek oraz skierowanie reszty na przemiał do papierni. Jeszcze w 1959 r. nieopracowane wydawnictwa poniemieckie liczyły 19559 woluminów. Część z nich (7893 woluminy — głównie wydawnictw urzędowych) przekazano w tymże roku Bibliotece Państwowej Niemieckiej Republiki Demokratycznej w Berlinie przy współpracy polskiego Ministerstwa Spraw Zagranicznych i ambasady NRD w Warszawie. Można dodać, że porządkowanie ostatnich elementów tego księgozbioru zakończono dopiero w latach dziewięćdziesiątych ubiegłego stulecia.

Wśród specyficznych dla okresu komunistycznego sposobów gromadzenia zbiorów - dobrze jednak oddających atmosferę tamtych lat - można wspomnieć pozyskiwanie książek i czasopism z Głównego Urzędu Kontroli Prasy, Publikacji i Widowisk, czyli po prostu z cenzury. W 1953 r. pochodziło stamtąd 15\% wpływów nowych książek (790 tytułów) i spora liczba egzemplarzy prasy i periodyków ${ }^{41}$. W 1954 r. BS otrzymała w formie darów 387 woluminów, z czego aż 342 pochodziły z Głównego Urzędu Kontroli Prasy, Publikacji i Widowisk. Współpraca ta, chwalona przez bibliotekarzy ze względu na rozmiar i szybkość otrzymywania nowości, została ograniczona w 1967 r., kiedy kierownictwo cenzury zezwoliło na przekazywanie jedynie periodyków. „Wpłynęło to na zmniejszenie się ilości wydawnictw zwartych wpływających do Biblioteki bezpłatnie" ${ }^{42}$. Podobny choć znacznie bardziej pracochłonny dla bibliotekarzy był sposób wspierania gromadzenia prasy zagranicznej przez Wydział Prasowy

40 Wytyczne pracy...

${ }^{41}$ Sprawozdanie z pracy Biblioteki za rok 1953. Plan pracy na rok 1954, oprac. Z. Hryniewicz, Biblioteka Sejmowa, Warszawa 1954, s. 11 (maszynopis w zbiorach BS).

${ }_{42}$ Sprawozdanie z działalności za okres IV kadencji Sejmu PRL 1965-1969, Warszawa 1969, s. 6 (maszynopis w zbiorach BS). 
Ministerstwa Spraw Zagranicznych. Raz lub dwa razy do roku przywożono 3-4 tony gazet i czasopism, spośród których mozolnie wyszukiwano ich brakujące numery w zasobach biblioteki lub formowano całe ciągi ${ }^{43}$.

Biblioteka starała się rozbudowywać gromadzenie poprzez wymianę wydawnictw. Mimo formalnego obowiązywania konwencji brukselskiej z 1886 r. wymiana była ograniczana najczęściej z przyczyn politycznych. Na przykład gdy władze komunistyczne zamknęły działający w Warszawie brytyjski Ośrodek Informacyjny, Brytyjczycy w ramach retorsji wstrzymali m.in. wysyłkę materiałów parlamentarnych dla BS. Ponadto w latach pięćdziesiątych wszelkie kontakty z obcymi instytucjami podlegały kontroli lub pośrednictwu Ministerstwa Spraw Zagranicznych, które często utrudniało lub spowalniało tempo wymiany. Aby utrzymać ciągłość wydawnictw parlamentarnych, BS przez kilka lat była zmuszona dokonywać zakupu dokumentów, m.in. brytyjskich, austriackich, niemieckich, izraelskich i jugosłowiańskich, ze skromnego przydziału dewiz. Po $1956 \mathrm{r}$. sytuacja w tym zakresie zaczęła się poprawiać. W 1959 r. BS otrzymywała wydawnictwa urzędowe i parlamentarne już z 34 państw i stan ten utrzymywał się na zbliżonym poziomie aż do końca lat dziewięćdziesiątych, kiedy druki zostały zastąpione przez parlamentarne i urzędowe bazy danych. Oczywiście głównym sposobem pozyskiwania tych wydawnictw była wymiana, a ponieważ żaden rodzaj kontaktów z zagranicą pod rządami komunistów nie mógł się odbywać bez kontroli władz, w 1960 r. powołano komisję do spraw wymiany pod przewodnictwem szefa Kancelarii Sejmu, który — zupełnie niekompetentny — zapewniał stosowny nadzór polityczny nad jej działaniami. Jako przykład można wskazać, że każdorazowa wysyłka materiałów do Biblioteki Publicznej Nowego Jorku (New York Public Library) oraz każda korespondencja wymagała odrębnej zgody szefa Kancelarii Sejmu. Wydał on nawet specjalną instrukcję w sprawie wymiany wydawnictw sejmowych. Również wskutek nacisku politycznego wspomniana komisja do spraw wymiany postanowiła zaprzestać wysyłki polskich parlamentariów do biblioteki Bundestagu. Przez cztery lata wymiana miała charakter jednostronny, aż na początku 1965 r. Niemcy, wobec braku odpowiedzi na ich pisma i nieotrzymywania materiałów polskich, zaprzestali wysyłania dokumentacji Bundestagu. Próba ratowania tego kontaktu napotkała twardy opór ze strony polskiego MSZ, które zakazało „w obecnej sytuacji politycznej" odnowienia wymiany ${ }^{44}$. Wznowiono ją dopiero po $1970 \mathrm{r}$. W latach pięćdziesiątych i sześćdziesiątych ingerencje ze strony władz w politykę gromadzenia były dość częste, na przykład w 1954 r. Państwowa Komisja Planowania Gospodarczego bez konsultacji z Kancelarią Rady Państwa i BS skreśliła z listy prenumeraty szereg tytułów pism zagranicznych. Fatalnie działało przedsiębiorstwo „Ruch” - państwowy monopolista w kolportażu obcych czasopism. Biblioteki nie ominęła też plaga wycofywania książek uznanych za szkodliwe z powodów ideologicznych.

${ }^{43}$ Konferencja na temat „Polityka kompletowania ksiegozbioru”: projekt referatu, akceptowany przez Z. Hryniewicz, Biblioteka Sejmowa, Warszawa 1957, s. 9 (maszynopis w zbiorach BS).

44 Sprawozdanie z działalności za okres III kadencji Sejmu PRL 1961-1965, Biblioteka Sejmowa, Warszawa 1966, załącznik 3, s. 9 (maszynopis w zbiorach BS). 
Centralny Zarząd Bibliotek sporządził w końcu lat czterdziestych listę tytułów zakazanych, a specjalna komisja wycofała je z zasobu BS i przekazała na przemiał. Wobec niezbyt w tym czasie dokładnej ewidencji wydawnictw zwartych trudno jest dziś określić rozmiary tego — jak napisała dyrektor Biblioteki Zofia Hryniewicz „pogromu” ${ }^{4}$.

Dla pełniejszego obrazu sytuacji należy dodać, że po przeprowadzeniu tej akcji minister oświaty wydał we wrześniu 1950 r. zarządzenie w sprawie gromadzenia, przechowywania i wyjątkowego udostępniania w bibliotekach druków wycofanych z obrotu ${ }^{46}$. Niszczenie książek po doświadczeniach hitleryzmu kojarzyło się zdecydowanie źle, wybrano więc opcję wyznaczenia grupy uprzywilejowanych bibliotek (w tym m.in. Sejmowej, Narodowej, Centralnej Wojskowej), którym zezwolono na posiadanie druków bezdebitowych. Nadzór nad nimi miał pełnić ,,pod osobistą odpowiedzialnością" dyrektor biblioteki, miały powstawać oddzielne inwentarze i niedostępne dla zwykłych czytelników osobne katalogi. Fizycznie druki te należało ustawić „W wydzielonym do tego celu pomieszczeniu, które dyrektor biblioteki winien osobiście utrzymywać pod stałym zamknięciem". W 1954 r. rozszerzono listę uprawnionych bibliotek i nakazano składanie corocznego sprawozdania z działalności działu prohibitów ${ }^{47}$. Po październiku 1956 r. regulacje te zostały uchylone, a przyjęto jedynie, że „ze względu na interes publiczny zakres udostępniania niektórych kategorii druków powinien być ograniczony regulaminem wewnętrznym biblioteki jedynie do badań naukowych, studiów oraz działalności literackiej, publicystycznej i urzędowej”48. W BS książki należące do tej kategorii oznaczano - jak na ironię — sygnaturą "Cim” (od „cymelia”), a kolekcja została włączona do ogólnego zbioru dopiero w latach dziewięćdziesiątych. Ale już wcześniej, kierujący BS w latach 1971-1981 Tadeusz Kozanecki znany był z szerokiego udostępniania ,prohibitów” naukowcom, publicystom czy posłom.

Po okresie bardzo szybkiego przyrostu zasobu w połowie lat pięćdziesiątych nastąpiła względna stabilizacja na poziomie 3500-4000 wydawnictw zwartych rocznie. Wobec występowania w zachowanych dokumentach różnych sposobów liczenia wpływów (woluminy, egzemplarze, zeszyty, jednostki biblioteczne etc.) przeprowadzenie dokładnej charakterystyki gromadzenia wymagałoby odrębnych studiów a czasem skomplikowanych obliczeń.

Podana w wewnętrznym dokumencie z 1957 r. liczba 300 tys. woluminów w zasobie BS wydaje się z różnych względów szacunkowa i znacznie zawyżona. Bliższymi

${ }^{45}$ Konferencja na temat..., s. 10-11.

${ }^{46}$ Zarządzenie Ministra Oświaty z dnia 2 września 1950 r. w sprawie gromadzenia, przechowywania i wyjątkowego udostępniania w bibliotekach druków wycofanych z obrotu, M.P. z 1950 r. nr A-99, poz. 1249.

${ }^{47}$ M.P. z 1955 r. nr 12, poz. 130.

${ }^{48}$ Zarządzenie Ministra Kultury i Sztuki z dnia 18 stycznia 1957 r. uchylające zarządzenie Ministra Oświaty z dnia 2 września 1950 r. w sprawie gromadzenia, przechowywania i wyjątkowego udostępniania w bibliotekach druków wycofanych z obrotu, M.P. z 1957 r. nr 7, poz. 56. 
rzeczywistości danymi dysponujemy od roku 1959 i w największym skrócie są one następujące (podane liczby odpowiadają sumie woluminów wydawnictw zwartych, parlamentarnych i urzędowych, organizacji międzynarodowych, periodyków i wydawnictw kartograficznych; tabela 1):

Tabela 1. Liczba zbiorów Biblioteki Sejmowej w latach 1959-1989

\begin{tabular}{|c|c|c|}
\hline Lp. & Rok & Ogólny stan zbiorów na koniec roku w woluminach \\
\hline 1 & 1959 & 156681 \\
\hline 2 & 1964 & 190281 \\
\hline 3 & 1968 & 204898 \\
\hline 4 & 1973 & 207456 \\
\hline 5 & 1979 & 211163 \\
\hline 6 & 1985 & 237811 \\
\hline 7 & 1989 & 253595 \\
\hline \multicolumn{2}{|l}{ Średni, roczny wpływ: 3231 woluminów } \\
\hline
\end{tabular}

Źródło: opracowanie własne.

Jeżeli przypomnimy, że gromadzenie zaczęto pod koniec 1944 r. od poziomu zerowego, to pierwsze piętnastolecie daje imponujące rezultaty. Pamiętać jednak należy, że znaczna część zasobu nie była należycie zewidencjonowana i opracowana. Wyhamowanie tempa przyrostu w połowie lat sześćdziesiątych miało kilka przyczyn. Zaprzestano administracyjnych ,przydziałów” książek, a wiele z przydzielonych wcześniej wycofano z zasobu jako dublety lub pozycje nieodpowiadające profilowi zbiorów. Ustał nacisk władz na gromadzenie wielu egzemplarzy wielotomowych wydawnictw ideologicznych (literatura marksistowsko-leninowska), pozbywano się zdezaktualizowanych roczników prasy, wreszcie do selekcji zmuszała ograniczona powierzchnia magazynów i brak perspektyw jej przyrostu.

Mimo trudności i wspomnianych przeszkód w wymianie materiałów parlamentarnych udało się jednak obronić pożądany profil gromadzenia. W 1989 r. w zasobie znajdowało się m.in. 55621 woluminów wydawnictw urzędowych, parlamentarnych, organizacji międzynarodowych, często jedynych egzemplarzy w kraju, których gromadzenie uważane było za element podstawowej misji BS. Warto dodać, że w gromadzonych wydawnictwach zwartych odsetek pozycji obcojęzycznych zwykle przekraczał 50\% nabytków, co w krajach obozu komunistycznego nie było zjawiskiem częstym.

Dzięki usytuowaniu przy Sejmie, formalnie najwyższym organie władzy, BS uzyskiwała pewne minimum autonomii w zakresie gromadzenia materiałów obcojęzycznych, jak również stosowne przydziały dewiz na ich zakup. Publikowano również 
egzemplarze obowiązkowe druków urzędowych w formie dzienników urzędowych ministerstw oraz dzienników urzędowych wojewódzkich rad narodowych ${ }^{49}$. Z egzekwowaniem tych egzemplarzy, szczególnie z ministerstw, bywały kłopoty, ale w koncu udało się zgromadzić niemal kompletny zbiór. Od wznowienia działalności po wojnie BS pozostawała też biblioteką depozytarną ONZ i mimo propozycji rezygnacji z depozytu utrzymała ten status do dziś.

Przez cały omawiany okres krytycznej ocenie poddawano jeden z najważniejszych fragmentów pracy bibliotekarskiej, a mianowicie opracowanie. Stosunkowo nieliczny personel nie był w stanie - przy tak znacznym wpływie materiałów — zapewnić rytmicznej i wykonywanej na bieżąco inwentaryzacji oraz katalogowania tak formalnego, jak i przedmiotowego. Przez lata nad działem opracowania ciążył lawinowy wpływ wydawnictw z okresu powojennej organizacji biblioteki. Zaległości, skrzętnie ukrywane w sprawozdaniach, można dostrzec w nonsensownych planach pracy i ,wytycznych do działalności" na kolejne lata, w których przez dłuższy czas przewidywano skatalogowanie tych samych zasobów. Dyrektor BS jeszcze w 1959 r. skarżyła się w półoficjalnym dokumencie: „W okresach ubiegłych bibliotekarze fachowi byli zabierani do obsługi posiedzeń sejmowych, do zastępstw nieobecnych sekretarek i masowo do pracy na innym terenie - np. wykopki, żniwa" ${ }^{50}$. Niełatwym zadaniem było katalogowanie parlamentariów zagranicznych, najczęściej będących jedynymi tego rodzaju wydawnictwami w kraju. Przyjęto tu zasadę autorstwa korporatywnego (nazwę instytucji). Karty katalogowe były układane według państw, a w ich obrębie według instytucji. Prowadzito to niekiedy do błędnego zaliczania wydawnictw zwartych wydawanych przez parlament do parlamentariów. Starano się nadrabiać zaległości, np. w latach 1961-1965 obok opracowania na bieżąco 2744 woluminów wydawnictw parlamentarnych skatalogowano także 1502 woluminy zaległe. Głównym powodem narastających zaległości była jednak niedostateczna obsada kadrowa. Sytuacja stała się krytyczna na przełomie lat sześćdziesiątych i siedemdziesiątych, kiedy zaległości w opracowaniu zbiorów sięgnęły kilku lat, a liczba druków zupełnie nieopracowanych wzrosła do około 30 tys. woluminów (niemal 15\% ogółu zbiorów).

W celu zaradzenia tym negatywnym zjawiskom, prawdopodobnie z inicjatywy nowego (od grudnia 1971 r.) dyrektora BS Tadeusza Kozaneckiego, został przygotowany przez komisję bibliotekarzy ekspertów raport pod tytułem Biblioteka Sejmowa, stan obecny, wnioski, propozycje. Opisano w nim zły stan lokalowy (BS dysponowała powierzchnią około 1 tys. $\mathrm{m}^{2}$, za docelową uznano 4 tys. $\mathrm{m}^{2}$ ), zaproponowano wzrost zatrudnienia (z 17 do 29 pracowników merytorycznych) i reorganizację struktury w dwóch wariantach. Wskazano na konieczność selekcji wydawnictw ciągłych, przede wszystkim prasy oraz powołania zespołu do spraw polityki gromadzenia zbiorów. W podsumowaniu raportu znalazło się stwierdzenie: „dalsze pozostawianie Biblioteki Sejmowej w dotychczasowym stanie [...] prowadzi do regresu

49 Okólnik nr 15 Prezesa Rady Ministrów z dnia 21 kwietnia 1950 r w sprawie nadsyłania do Biblioteki Sejmowej wydawnictw urzędowych, M.P. z 1950, r. nr A-53, poz. 605.

${ }^{50}$ Konferencja na temat..., s. 20. 
jej sprawności informacyjnej. Tylko natychmiastowa pomoc udzielona Bibliotece przez władze Sejmu może zapewnić jej niezbędne warunki rozwoju" ${ }^{\text {". }}$. Jednym z rezultatów raportu było spotkanie lobby bibliotekarskiego z szefem Kancelarii Sejmu i jej wyższymi urzędnikami. Uczestniczyli w nim m.in. dyrektorzy dwóch największych bibliotek w kraju (Biblioteki Narodowej i Biblioteki Jagiellońskiej), dyrektor współpracującej z BS Biblioteki Szkoły Głównej Planowania i Statystyki, a także autorki raportu. Podjęto tematy wielokrotnie już omawiane w przeszłości ze starym dylematem związanym z profilem zbiorów biblioteki parlamentarnej na czele: czy należy dążyć do ukształtowania wyraźnie specjalistycznego zasobu (dokumentacja parlamentarna, legislacja, prawo), czy też, ulegając naciskom posłów, rozszerzać zakres gromadzenia na większość problematyki będącej przedmiotem zainteresowania parlamentu? Opowiedziano się za specjalizacją i selekcją zbiorów, reorganizacją i wzmocnieniem kadrowym BS i - co więcej — uzyskano akceptację kierownictwa Kancelarii Sejmu.

Wynikiem tych prac była częściowa reorganizacja BS, wyrażająca się w utworzeniu działu dokumentacji parlamentarnej, który miał dokonywać analizy dokumentacyjnej parlamentariów i druków zwartych poświęconych praktyce i teorii parlamentaryzmu, jak też udzielać w tym zakresie informacji użytkownikom. Nastąpiło wzmocnienie kadrowe. O ile w 1973 r. było zatrudnionych 21 pracowników, to w 1974 już 27 i stan ten nie ulegał większym zmianom przez następne 15 lat, czyli do końca omawianego okresu.

Przez cały okres powojenny BS była nakierowana przede wszystkim na obsługę posłów i organów Sejmu (komisje). Kategorie obsługiwanych użytkowników w latach 1947-1989 nie ulegały większym zmianom. Obok członków rządu, posłów i członków Rady Państwa, personelu obu kancelarii, należeli tu również pracownicy naukowi, dziennikarze, publicyści oraz studenci wyższych lat studiów, obsługiwani w zależności od intensywności prac Sejmu w szerszym lub węższym zakresie. W latach 1944-1949 liczba czytelników wynosiła od pięciu do 50 dziennie, a szczegółowa statystyka nie była prowadzona. W 1953 r. czytelnię odwiedziło 1914 użytkowników. W sprawozdaniu z tego roku skonstatowano z niezadowoleniem, że wskutek działań ochrony budynku Sejmu ,wytworzyła się opinia, że Biblioteka Sejmowa jest biblioteką zamkniętą, mało dostępną", domagano się sprostowania tej opinii na łamach prasy. W 1956 r. liczba odwiedzin czytelników osiągnęła już prawie 9 tys. (8819), by w następnych trzydziestu latach oscylować pomiędzy 7500 a 13500 odwiedzin rocznie. Charakterystyczny spadek nastąpił w 1968 r. (do 6100), gdy z powodu wydarzeń na wyższych uczelniach (marzec 1968), ograniczono administracyjnie dopływ studentów (od końca lutego do połowy sierpnia po prostu nie wydawano przepustek).

Dla każdej biblioteki parlamentarnej jednym z istotnych wyznaczników jej przydatności była liczba posłów korzystających ze zbiorów. Nie dysponujemy tutaj pełnymi

${ }^{51}$ M. Jasińska, W. Piusińska, A. Romańska, Biblioteka Sejmowa: stan obecny, wnioski, propozycje: raport Komisji Bibliotekarzy-Ekspertów, Warszawa, październik 1972, s. 15 (maszynopis w zbiorach $\mathrm{BS})$. 
danymi, ale wiemy, że w latach 1959-1968 bibliotekę odwiedzało średnio 140 posłów rocznie (na ogólną liczbę posłów 460) ${ }^{52}$. W drugiej połowie lat osiemdziesiątych posłowie stanowili od 6 do 11\% użytkowników. Warto dodać, że udział posłów i senatorów gwałtownie wzrósł w pierwszych latach po przemianach roku 1989. W $1991 \mathrm{r}$. czytelnię odwiedziło 320 posłów i senatorów, a stanowili oni blisko $20 \%$ wszystkich użytkowników (tabela 2).

Tabela 2. Obsługa posłów i senatorów w latach 1985-1991

\begin{tabular}{|c|c|c|c|c|}
\hline Lp. & Rok & Ogólna liczba odwiedzin & W tym posłów & $\%$ \\
\hline 1 & 1985 & 7394 & 831 & 11,0 \\
\hline 2 & 1986 & 8450 & 466 & 6,0 \\
\hline 3 & 1987 & 8828 & 723 & 8,2 \\
\hline 4 & 1988 & 8660 & 581 & 6,7 \\
\hline 5 & $1989 *$ & 9022 & 1082 & 10,8 \\
\hline 6 & 1990 & 11899 & 2020 & 17,0 \\
\hline 7 & 1991 & 9569 & 1676 & 20,0 \\
\hline
\end{tabular}

* Od lipca 1989 r. funkcjonował liczący 100 członków Senat. Biblioteka podjęła obsługę senatorów na zasadach analogicznych jak w przypadku posłów.

Źródło: opracowanie własne.

Z dzisiejszej perspektywy taką frekwencję posłów należy uznać za dobrą. Jednak kierownictwo BS oceniało ją za niedostateczną i wielokrotnie zastanawiało się nad sposobami jej zwiększenia. Za przyczynę niedostatecznej liczby użytkowników uznawano m.in. brak oddzielnej i bardziej komfortowej niż ogólnodostępna czytelni poselskiej. Zawsze istniał też dylemat wyboru między dbałością o ścisłe zachowanie ustalonego profilu zbiorów a zgłaszanymi przez posłów potrzebami, sięgającymi nierzadko literatury pięknej.

W celu uzyskania akceptacji dla zakresu gromadzenia, metod pracy oraz potrzeb lokalowych organizowano lub inspirowano konferencje z udziałem władz Sejmu. Spotkania takie odbyły się w latach 1949, 1960, 1964 oraz 1972. Mimo uzyskiwanego w trakcie tych spotkań poparcia ze strony wysoko postawionych osób sprawy BS grzęzły w administracyjnych procedurach i braku środków budżetowych. Może tylko wspomniana narada z 1972 r. dała impuls do konkretnych działań. Podjęto wówczas prace nad koncepcją automatyzacji czynności bibliotecznych. Inicjatorem i gorącym zwolennikiem wykorzystania informatyki zarówno w Sejmie, jak i w bibliotece był jej dyrektor Tadeusz Kozanecki. We wrześniu 1972 r. powołano zespół roboczy pod

${ }^{52}$ W latach: $1959-142 ; 1964-147 ; 1968-140$. 
przewodnictwem zastępcy sekretarza naukowego Polskiej Akademii Nauk, który przygotował raport pod tytułem Forum - System informatyczny dla potrzeb Sejmu.

System miał w sposób wszechstronny obsługiwać informacyjnie posłów, komisje sejmowe oraz Prezydium Sejmu, a efektami jego zastosowania powinno być poprawienie sytuacji informacyjnej Sejmu, m.in. przez likwidację szumu informacyjnego przy jednoczesnym zapewnieniu automatycznego szerokiego dostępu do informacji pożądanej. Koordynatorem tego niesłychanie ambitnego zadania została BS. Prowadzono intensywne prace studialne, starając się o ich kompatybilność z tworzonym wówczas, gigantycznym w założeniu, państwowym systemem Specjalistycznej Informacji Naukowej, Technicznej i Organizacyjnej (SINTO). Planowano taki rozwój funkcji BS, aby stała się ona centralnym ośrodkiem informacji legislacyjnej. Powołano nawet 16-osobową (czyli praktycznie niezdolną do efektywnego działania) Radę Programową Zautomatyzowanego Systemu Informacji „Biblioteka Sejmowa - Centralny Ośrodek Informacji Legislacyjnej”. Na początku 1975 r. utworzono w BS Pracownię Informatyki (1975 r. — 4,5 etatu, 1976 r. — 12 etatów), której zadaniem było projektowanie i wdrażanie koncepcji wspomnianego centralnego ośrodka informacji legislacyjnej. W miarę postępu prac, liczenia kosztów i porównania koniecznych nakładów z potencjalnymi efektami przy zastosowaniu ówczesnej techniki komputerowej rezygnowano z kolejnych elementów monstrualnego systemu (np. pełnych tekstów ustaw), ograniczając się w końcu do elektronicznej informacji adresowej o polskim ustawodawstwie aktualnym i obowiązującym w przeszłości (wstecz do 1918 r.). Praktycznie system miał odpowiadać na pytanie, w jakich aktach normatywnych zawarte są przepisy prawne odnoszące się do określonej materii oraz czy i jakie akty wydano w przedmiocie wykładni i stosowania tych przepisów. Zakończenie budowy tego - według dzisiejszych standardów — nieskomplikowanego systemu przewidywano na rok 1985. Można dodać, że Pracownia Informatyki przekształciła się w ciągu kilku lat w Ośrodek Informatyki, który został wydzielony ze struktury organizacyjnej BS w samodzielną jednostkę.

Obok rejestru aktów normatywnych elementem systemu miał być centralny kata$\log$ literatury prawniczej, obejmujący informacje o książkach, czasopismach, wydawnictwach parlamentarnych, urzędowych i organizacji międzynarodowych oraz wydawnictwach niesamoistnych $\mathrm{z}$ dziedziny prawa znajdujących się $\mathrm{w}$ zbiorach BS oraz 17 innych bibliotek prawniczych (w tym ośmiu bibliotek uniwersyteckich wydziałów prawa). Dla ułatwienia koordynacji prac w 1979 r. BS przyznano status Centralnej Biblioteki Legislacyjnej, nakładający w teorii szereg obowiązków w zakresie gromadzenia i opracowania zbiorów, ale ponieważ za ogólnymi ideami nie stanęły żadne środki finansowe, szczególnych sukcesów na tym polu nie odnotowano. Równolegle podjęto prace zmierzające do wprowadzenia automatyzacji procesów bibliotecznych. W $1977 \mathrm{r}$. opracowano analizę systemową BS, w której określono podstawowe zadania organizacyjne, szkoleniowe i badawcze konieczne do zrealizowania przy zamianie tradycyjnych metod bibliotecznych na metody informatyczne. Kryzys końca lat siedemdziesiątych przyczynił się do zatrzymania dalszych prac, co wobec postępów techniki komputerowej doprowadziło do ich całkowitej dezaktualizacji. 
Przez cały okres powojenny BS zmagała się z brakiem odpowiednich powierzchni magazynowych i przeznaczonych na pracownie biblioteczne. W 1946 r. magazyny zlokalizowano w pomieszczeniach zajmowanych w latach 1928-1939, a czytelnię w przyległej okrągłej sali komisji budżetowej. Lokale te BS zajmuje do dziś. Wyposażenie czytelni zostało zaprojektowane przez światowej sławy architekta wnętrz Jana Bogusławskiego. Był on dwukrotnym zdobywcą grand prix na wystawach światowych (Paryż 1937 r. i Nowy Jork 1939 r.) za projekty wnętrz prezentowanych w pawilonie polskim. Rozgłos przyniósł mu projekt kołyski dla holenderskiej księżniczki Beatrix (1938 r.), a wyposażenie czytelni BS uchodzi za jedną z jego najlepszych realizacji ${ }^{53}$.

Początkowo BS zajmowała powierzchnię około $1000 \mathrm{~m}^{2}$, z biegiem czasu zwiększyła się ona do $1500 \mathrm{~m}^{2}$, ale przez większość okresu występowały problemy zarówno z powierzchnią magazynową, jak i przeznaczoną dla użytkowników i pracowników. Z powierzchnią magazynową radzono sobie przez selekcję zasobu (głównie przekazywanie innym bibliotekom gromadzonej i oprawianej prasy) oraz przez podwyższanie regałów - oczywiście do pewnych granic. Przez długie lata domagano się pomieszczenia na zorganizowanie czytelni dla posłów — były i dezyderaty poselskie w tej sprawie - ale niczego nie uzyskano. W planach powojennej odbudowy zaprojektowano co prawda wyodrębniony w kompleksie gmachów sejmowych budynek dla biblioteki, ale gdy został on zrealizowany, przeznaczono go na inne cele, m.in. na gabinety członków Rady Państwa oraz dla centralnego archiwum partii komunistycznej. Obecnie jest on siedzibą Senatu. Po uchwaleniu stalinowskiej konstytucji w 1952 r. władza komunistyczna straciła zupełnie zainteresowanie dla dalszej, zgodnej z projektem odbudowy gmachów sejmowych i kolejny planowany dla biblioteki budynek nie powstał. Do 1989 r. nie doczekały się realizacji również kilkukrotnie formułowane projekty pozyskania nowych pomieszczeń w istniejących gmachach, a wyposażenie techniczne (regały, windy, oświetlenie i ogrzewanie, zabezpieczenie przeciwpożarowe) pozostawało na poziomie osiągniętym w latach pięćdziesiątych.

\section{W WOLNEJ POLSCE - BIBLIOTEKA SEJMOWA PO 1989 R.}

Po częściowo wolnych wyborach z 4 czerwca 1989 r. uległa zmianie pozycja parlamentu w systemie organów władzy. Zamiast fasadowej instytucji realizującej formalnie decyzje podejmowane przez partię komunistyczną, Sejm stał się bodaj najważniejszym miejscem rozstrzygania spraw o decydującym dla społeczeństwa i państwa znaczeniu. Nastąpiła niespotykana wcześniej intensyfikacja prac obradującego w permanencji (w miejsce wcześniejszego systemu dwóch sesji w roku) parlamentu. Kancelaria Sejmu stanęła przed zupełnie nowymi i zwielokrotnionymi zadaniami, zarówno kontekście ilości, jak i jakości usług na rzecz izby. Z powodu zmiany stylu pracy Sejmu wyraźnie wzrosło zapotrzebowanie zarówno na informację, jak i na bieżące wsparcie eksperckie. Niezbędne stało się zorganizowanie zarówno własnego

\footnotetext{
${ }^{53}$ K. Grobelska, Meble i wnętrza Jana Bogusławskiego, „Architektura” 2002, nr 5, s. 55-58.
} 
biura studiów i ekspertyz, jak i wzmocnienie oraz ujednolicenie zaplecza informacyjno-dokumentacyjnego Sejmu.

Biblioteka Sejmowa pozostała jednostką organizacyjną Kancelarii Sejmu, ale jej funkcje uległy rozszerzeniu. Na podstawie porozumienia między szefami Kancelarii Sejmu i odrębnej w polskich warunkach Kancelarii Senatu, użytkownikami biblioteki w zakresie analogicznym do posłów stali się senatorowie oraz pracownicy zaplecza senackiego. Finansowanie nadal pochodziło wyłącznie z budżetu Kancelarii Sejmu. W pierwszych latach przemian nastąpiła rozbudowa struktury BS przez tworzenie lub przyłączanie nowych agend.

Wobec wzmożenia prac Sejmu i konieczności zapewnienia pomieszczeń na potrzeby bieżącej działalności komisji sejmowych, w 1990 r. zrezygnowano z mającej kilkuletnią historię idei utworzenia muzeum Sejmu Polskiego, a zespół zajmujący się dotąd jego organizacją przeszedł do BS, tworząc Wydział Muzealiów. Wydział zajmuje się do dzisiaj gromadzeniem i opracowaniem muzealnym dzieł sztuki, pamiątek kultury materialnej i starodruków związanych z przeszłością parlamentaryzmu. Organizuje też lub jest współorganizatorem licznych wystaw czasowych, a także konferencji, najczęściej dla uczczenia ważnych w dziejach Sejmu rocznic. Aktualnie zasób Wydziału zbliża się do 8300 jednostek (przedmioty sztuki, dokumenty, numizmaty).

W odpowiedzi na zapotrzebowanie posłów na informację medialną w 1991 r. utworzono Mediatekę, zajmującą się rejestracją, opracowaniem i udostępnianiem nagrań wideofonicznych obrad Sejmu oraz ważniejszych informacyjnych i publicystycznych audycji z kilku kanałów telewizyjnych. Jej usługi stały się popularne wśród posłów, którzy zlecali rejestrację swoich wystąpień na kasetach wideo, potem na płyty DVD, a od kilku lat również na przenośne dyski zewnętrzne. Obok Mediateki utworzono również Dział Informacji Prasowej wytwarzający początkowo w formie papierowej dzienny i tygodniowy przegląd prasy o Sejmie oparty na szerokim wyborze gazet i czasopism, zarówno centralnych, jak i regionalnych. W 2005 r. został uruchomiony elektroniczny serwis informacji prasowej, umożliwiający bezpośredni dostęp do zbioru wycinków prasowych i jego pełnotekstowe przeszukiwanie.

Po samorozwiązaniu partii komunistycznej część jej majątku pozostała niezagospodarowana i brakowało jasnej koncepcji co do jej dalszych losów. Dotyczyło to m.in. bibliotek. Jedna z nich — istniejąca przy byłym Archiwum Komitetu Centralnego Polskiej Zjednoczonej Partii Robotniczej (przejętym przez archiwum państwowe, ale bez księgozbioru) — została na mocy decyzji Szefa Kancelarii Sejmu z kwietnia 1991 r. włączona do BS. Rozwiązanie to prawdopodobnie uratowało księgozbiór przed rozproszeniem, ale wymagało poważnej pracy organizacyjnej. Znaczna część woluminów była składowana w stertach w piwnicach budynku adaptowanego właśnie na potrzeby Senatu, bez żadnej logiki i wskazówek topograficznych. Po trwających blisko rok pracach porządkowych udało się ponownie udostępnić zbiory czytelnikom. Charakteryzują się one dużym zróżnicowaniem tematycznym — od bogato reprezentowanego marksizmu i lewicowych ruchów politycznych, aż po kolekcję prasy podziemnej okupowanej Polski. Założono dalszy rozwój liczącego blisko 145 tys. woluminów 
zbioru, ze szczególnym uwzględnieniem problematyki przemian zachodzących w Europie Środkowej i Wschodniej po 1989 r. oraz lewicowych ruchów politycznych i społecznych. Stanowi to nawiązanie do tradycji z okresu międzywojennego, gdy BS gromadziła kolekcję dzieł poświęconych bolszewizmowi. Ponadto podjęto gromadzenie dokumentów życia politycznego, czyli okazjonalnych wydawnictw partii politycznych i związków zawodowych (programy, statuty, ulotki i plakaty wyborcze etc.), których zbiór przekroczył już 19900 jednostek. Przejęta biblioteka pozostaje wyodrębniona jako Wydział Zbiorów Historii Społecznej Biblioteki Sejmowej. Jako wydział funkcjonuje także włączone do BS we wrześniu 1992 r. Archiwum Sejmu. Gromadzi ono, opracowuje, przechowuje i udostępnia dokumentację archiwalną wytworzoną przez Sejm, jego organy, biura poselskie i Kancelarię Sejmu. Także w tym wypadku świadomie nawiązano do tradycji z okresu II Rzeczypospolitej, ale rozwiązanie to było podyktowane również dążeniem do skupienia zaplecza dokumentacyjnego Sejmu w jednej jednostce organizacyjnej oraz względami utylitarnymi (eliminacja wielokrotnego gromadzenia niektórych dokumentów, łatwość dostępu archiwistów do materiałów źródłowych przechowywanych w bibliotece itp.). W 2018 r. Archiwum Sejmu posiadało w zasobie ponad 1500 metrów bieżących akt, około 74 tys. nagrań dźwiękowych i wideofonicznych (taśmy i kasety) i ponad 10 tys. zestawów fotografii.

W latach 2002-2018 w strukturze BS funkcjonował również Ośrodek Informacji i Dokumentacji Europejskiej [dalej: OIDE], którego zadaniem było prowadzenie obsługi informacyjnej w zakresie dokumentów i aktów prawnych Unii Europejskiej. $\mathrm{W}$ związku z jego powstaniem rozszerzono zakres gromadzenia literatury, czasopism i dokumentów unijnych. Powstała strona internetowa z bogatym zestawem na bieżąco aktualizowanych informacji o Unii Europejskiej i źródłach informacji unijnej, a także o działalności Sejmu w zakresie integracji europejskiej. W okresie okołoakcesyjnym (styczeń-lipiec 2004 r.) liczba wizyt użytkowników serwisu OIDE wyniosła 87771. OIDE uczestniczył również w projekcie Międzyparlamentarnej Wymiany Informacji w Sprawach UE (IPEX). Pracownicy OIDE w latach 2010-2011 brali udział w przygotowaniu i sprawowaniu polskiego przewodnictwa w Radzie UE, organizując szkolenia dla pracowników obu kancelarii — Sejmu i Senatu — i współtworząc witrynę internetową parlamentarnego wymiaru polskiej prezydencji oraz jej liczne podstrony. Należy podkreślić, że serwis ten został bardzo wysoko oceniony przez jego użytkowników, przedstawicieli licznych polskich i zagranicznych instytucji.

Najpoważniejszym wyzwaniem, przed jakim stanęła BS w ostatnim dwudziestoleciu, była automatyzacja prac bibliotecznych, rozumiana jako całkowita zmiana narzędzi pracy, nakierowana na zwiększenie efektywności i tempa obsługi użytkowników oraz — porównywalne może z wynalazkiem druku — poszerzenie dostępu do informacji poprzez strony internetowe. W 1992 r. ostatecznie została odrzucona wspomniana koncepcja zakładająca w teorii tworzenie gigantycznych systemów informatycznych, a w praktyce pozwalająca na realizację niekompatybilnych fragmentów o niewielkim zastosowaniu praktycznym. Idee tkwiące korzeniami w latach siedemdziesiątych uwarunkowane były z jednej strony poziomem rozwoju dostępnej techniki komputerowej, 
z drugiej zaś infrastrukturą państwa komunistycznego, które chcąc zachować centralną kontrolę nad całością systemu, ograniczało rozwój jego części składowych.

Podjęto decyzję o zakupie gotowego oprogramowania, należącego do klasy tzw. zintegrowanych systemów bibliotecznych, oznaczającą zasadniczy przełom zarówno w zakresie planowanej, jak i wdrożonej już automatyzacji. Po przeprowadzeniu konkursu ofert jesienią 1993 r. zainstalowano system Aleph, należący do rozwiązań średniej klasy, który jednak w pełni zaspokajał projektowane potrzeby BS. Elastyczność i modularna budowa systemu, odpowiadająca podstawowym funkcjom bibliotecznym (gromadzenie, opracowanie, udostępnianie oraz informacja o zbiorach), pozwalała na automatyzację wszystkich procesów bibliotecznych, a jednocześnie umożliwiała stopniowe uruchamianie kolejnych modułów. Taką właśnie strategię przyjęto w BS, jako że ani wyposażenie sprzętowe, ani ogrom prac związanych ze spolszczeniem anglojęzycznego systemu i dostosowaniem go do specyficznych potrzeb BS nie pozwalały na rozpoczęcie pracy we wszystkich modułach jednocześnie. Eksploatację systemu rozpoczęto od procesu katalogowania nowych nabytków, aby jak najszybciej udostępnić najbardziej widoczny dla użytkowników (i decydentów) fragment katalog najnowszych zbiorów. Do 1997 r. uruchomiono wszystkie moduły systemu. Równolegle prowadzono prace nad retrospektywną konwersją katalogów kartkowych do katalogu zautomatyzowanego. To niezwykle pracochłonne i trudne przedsięwzięcie wykonywane w różnych formach przez pracowników biblioteki zostało rozłożone na wiele etapów konsekwentnie realizowanych w poszczególnych latach. W trakcie realizacji następowały - uwarunkowane rozwojem techniki komputerowej i otoczenia bibliograficznego — zmiany metod pracy. Różna była jej intensywność, ale już w 1998 r. 96\% pozycji poszukiwanych przez użytkowników znajdowało się w katalogu zautomatyzowanym, co uwzględniając stosunkowo niewielkie nakłady na ten cel, należy uznać za wynik potwierdzający słuszność przyjętych na początku założeń. W 2008 r. zakończono retrokonwersję wydawnictw zwartych ze zbiorów głównych, w 2010 r. książek z zasobu Wydziału Zbiorów Historii Społecznej oraz polskich wydawnictw urzędowych, a w 2014 r. zagranicznych wydawnictw urzędowych i parlamentarnych. Obecnie realizowany jest ostatni etap prac nad retrospektywną konwersją opisów wydawnictw ciągłych.

Do najpoważniejszych problemów związanych $\mathrm{z}$ automatyzacją należała sprawa wyboru języka informacyjno-wyszukiwawczego odpowiadającego potrzebom biblioteki parlamentarnej. Po przeprowadzonej w 1992 r. analizie kilku takich języków, używanych zarówno w Kancelarii Sejmu, jak i innych polskich bibliotekach, przystąpiono do tworzenia własnego, jednolitego języka informacyjno-wyszukiwawczego, dostosowanego zarówno do zawartości treściowej dokumentów parlamentarnych (w tym aktów prawnych), jak i do wymogów systemu zautomatyzowanego. W ciągu dwóch lat udało się opracować jednolity system tezaurusów STEBIS (System Tezaurusów Biblioteki Sejmowej), za podstawę którego przyjęto wielojęzyczny tezaurus Parlamentu Europejskiego — EuroVoc. System ten jest stale aktualizowany i rozwijany (w 2018 r. zawierał około 11800 deskryptorów), a stała współpraca z zespołem tezaurusa EuroVoc polega m.in. na 
proponowaniu nowych deskryptorów oraz przekazaniu w 2005 r. na potrzeby Parlamentu Europejskiego oficjalnej, polskiej wersji językowej tezaurusa (od lipca 2005 r. jest ona dostępna w Internecie na stronie EuroVoc Thesaurus).

Posługiwanie się zintegrowanym systemem bibliotecznym wymusza na użytkowniku implementację jego kolejnych wersji, szczególnie jeżeli oznacza to zmianę generacyjną. W 2003 r., po 10 latach użytkowania tekstowego systemu Aleph 300 i blisko rocznym okresie przygotowań (zmiana platformy sprzętowej i szkolenia zespołu pracowników) BS podjęła prace w graficznym systemie Aleph 500. Ze względu na całkowicie zmienioną architekturę systemu, jak i nowy sposób zapisu i prezentacji danych, zmiana wymagała napisania własnych programów konwersji przy znacznym wysiłku zarówno ze strony administratorów systemu, jak i bibliotekarzy. W końcu 2003 r. nowy sposób pracy we wszystkich modułach systemu był w pełni opanowany, przy jednoczesnym utrzymaniu normalnego poziomu wszystkich prac bieżących. Aktualnie BS pracuje na wdrożonej w 2015 r. wersji 22 systemu Aleph, co również wymagało przebudowy platformy sprzętowej i podjęcia w szerokim zakresie szkolenia pracowników. W systemie Aleph utrzymywanych jest 16 baz danych, w tym 14 dostępnych ogółowi użytkowników poprzez stronę internetową. W 2018 r. liczba rekordów we wszystkich bazach wynosiła 1217 080, a liczba wejść użytkowników przekroczyła 700 tys.

W zakresie polityki gromadzenia zbiorów BS od 1989 r. stara się kierować konsekwentnie dwoma kryteriami. Pierwsze z nich — formalne - dotyczy oczywiście polskich i zagranicznych wydawnictw parlamentarnych i urzędowych oraz wybranych organizacji międzynarodowych. Drugie kryterium - treściowe - pozwala na wybieranie z polskiej i światowej oferty wydawniczej piśmiennictwa najbardziej odpowiadającego potrzebom Sejmu (jego funkcjom ustawodawczej i kontrolnej) oraz szeroko rozumianego zaplecza badawczego, doradczego oraz informacyjnego. Drugie kryterium jest oczywiście trudniejsze w realizacji, ale trzeba zaznaczyć, że po 1989 r. wobec zaniknięcia ograniczeń natury ideologiczno-politycznej (likwidacja prohibitów) i częściowo ekonomicznej (koniec księżycowej ekonomii komunistycznej i praktyczna wymienialność waluty) też otworzyły się nowe możliwości.

Zasady porządkujące i dyscyplinujące gromadzenie zbiorów zostały sprecyzowane w 1992 r. i w niewielkim stopniu zmodyfikowane w roku 1999. Specjalne badania bibliometryczne doprowadziły do korekty zestawu zagranicznych czasopism z zakresu prawa, na szeroką skalę prowadzona jest selekcja księgozbioru, a o zakupach literatury zagranicznej decyduje komisja, w skład której wchodzą profesorowie prawa publicznego o uznanej pozycji międzynarodowej. Ponadto można dodać, że możliwości finansowe BS zostały w latach dziewięćdziesiątych dostosowane do rzeczywistych potrzeb zakupu wydawnictw, a około $40 \%$ pozyskiwanych książek pochodziło z darów (szczególny wzrost zaznaczył się po uruchomieniu katalogu dostępnego online). Również około 40\% wszystkich nabytków stanowią wydawnictwa w językach obcych.

Piśmiennictwo gromadzone według kryteriów treściowych dotyczyło przede wszystkim prawa ze szczególnym uwzględnieniem prawa konstytucyjnego, parlamentarnego, 
administracyjnego, samorządowego, międzynarodowego, filozofii i socjologii prawa, zasad tworzenia oraz interpretacji prawa. Również publikacje dotyczące ustroju państwowego, politycznego, stosunków i organizacji międzynarodowych, nauk politycznych, ekonomii i historii były nabywane w komplecie lub w bogatym wyborze. Nawiązano w tym zakresie do profilu zbiorów z okresu II Rzeczypospolitej, a prowadzona selekcja wydawnictw zwartych dotyczyła pozycji spoza profilu i w pewnym stopniu propagandowej literatury komunistycznej. Pośrednim potwierdzeniem poprawności przyjętych założeń była i jest znikoma liczba wypożyczeń z innych bibliotek realizowanych na zamówienie posłów i senatorów.

W okresie 1991-2018 zasób BS wzrósł o przeszło 150 tys. woluminów książek, czasopism i wydawnictw urzędowych i wynosi obecnie ponad 557 tys. jednostek. Należy przy tym pamiętać, że w wyniku dokonywanej równolegle selekcji, której kryteria zostały zaostrzone w 1995 r., ze zbiorów usunięto we wspomnianym okresie około 80 tys. woluminów. Liczby te oznaczają wykonanie ogromnej pracy prowadzonej dla utrzymania kompletności i aktualności zbiorów w ramach założonego profilu gromadzenia.

Po 1989 r. nastąpiły bardzo istotne zmiany w sposobie sprawowania mandatu poselskiego, wymagające od parlamentarzysty nieporównanie większego zaangażowania w prace legislacyjne w Sejmie, a jednocześnie utrzymywania stałej aktywności w okręgu wyborczym. Posłowie uzyskali także możliwość zatrudniania personelu pomocniczego, do którego obowiązków należy m.in. zdobywanie informacji i różnorodne prace studialne na rzecz pracodawcy. Zjawiska te nie obniżyły jednak stopnia korzystania przez posłów z usług BS. Wobec średniej liczby wszystkich odwiedzin w roku, wynoszącej około 7 tys. wizyt, posłowie stanowili około 17\% użytkowników biblioteki, co oznaczało istotny wzrost w stosunku do lat 1985-1990, kiedy to posłowie stanowili 10\% użytkowników. W ostatnich latach w obu czytelniach (Głównej i Wydziału ZHS) posłowie składali przeciętnie 1500 wizyt rocznie.

We wprowadzonym w 1997 r. regulaminie obsługi użytkowników precyzyjnie określono ich kategorie, wśród których obok organów Sejmu, posłów, senatorów, pracowników obu Kancelarii, klubów poselskich, występują także inne osoby i instytucje, których potrzeby naukowe, zawodowe lub informacyjne mogą być zaspokojone na podstawie unikatowych zbiorów BS. Biblioteka stara się w praktyce prowadzić politykę ,półotwartych drzwi” uwarunkowaną wymogami bezpieczeństwa w dniach obrad plenarnych Sejmu, jak i niewielką czytelnią (24 miejsca). W 2018 r. pomieszczenia Czytelni Głównej i Informatorium przeszły gruntowny remont i otrzymały nową aranżację, m.in. nowe regały biblioteczne i biurka. Informatorium zostało wyposażone w nowoczesny, bezdotykowy skaner udostępniany czytelnikom, pozwalający na ochronę stanu zachowania kopiowanych materiałów. Skany są obecnie najpopularniejszą formą powielania materiałów bibliotecznych.

W ostatnich latach dzienna liczba odwiedzin czytelników nieznacznie spadła, co spowodowane jest przede wszystkim szerokim internetowym dostępem do parlamentarnych baz danych Kancelarii Sejmu i Senatu oraz do stale rosnących zbiorów cyfrowych 
udostępnianych na internetowej stronie BS — roczna liczba połączeń z bazami poprzez stronę internetową wzrosła w ostatnich 10 latach ponad sześciokrotnie.

Digitalizacja materiałów bibliotecznych i archiwaliów prowadzona jest od $2002 \mathrm{r}$. Rozważano kilka możliwych wariantów tego procesu. Przyjęto program udostępniania $\mathrm{w}$ formie obrazów szerokiej grupie użytkowników przede wszystkim polskiej dokumentacji parlamentarnej z okresu II Rzeczypospolitej (1919-1939). Stanowi to niewątpliwie element misji BS, a dotyczy materiałów najczęściej wykorzystywanych i z tego powodu zachowanych w złym stanie. Po zeskanowaniu sprawozdania stenograficzne i druki sejmowe na nośniku papierowym zostały poddane konserwacji i wycofane z bieżącego użytkowania.

Kolejny, będący w tej chwili na ukończeniu etap programu to digitalizacja parlamentariów z lat 1944-1993 (od 1993 r. działa pełnotekstowa baza danych utrzymywana przez Ośrodek Informatyki Kancelarii Sejmu). Następnie planowane jest cofnięcie się do okresu 1807-1918 (Sejm Księstwa Warszawskiego, Królestwa Kongresowego, Sejm Krajowy galicyjski). Realizacja tego programu prowadzi do powstania możliwie szerokiej i - co najważniejsze - ogólnodostępnej bazy źródłowej do dziejów polskiego parlamentaryzmu.

W ostatnich latach na stronie internetowej BS udostępniono również m.in. skany stenogramów obrad Okrągłego Stołu, biuletynów z posiedzeń Komisji Konstytucyjnej Zgromadzenia Narodowego z lat 1992-1997 i materiałów z prac Komisji Kodyfikacyjnej II RP. Powstało Wirtualne Muzeum Sejmu — portal, na którym prezentowane są wybrane najcenniejsze obiekty będące w zbiorach Wydziału Muzealiów, baza biograficzna Parlamentarzyści polscy, serwis Konstytucje świata oraz biblioteka cyfrowa prasy konspiracyjnej z lat 1940-1945.

Ważnym obszarem działalności BS są prace wydawnicze prowadzone już od początku lat dziewięćdziesiątych. Stopniowo miejsce niewielkich objętościowo i publikowanych w mikroskopijnych nakładach (np. 30 egzemplarzy) tłumaczeń aktów prawnych, zestawień bibliograficznych i informacyjnych, zajęły takie wydawane profesjonalnie i przeznaczone również na rynek księgarski serie wydawnicze, jak poprzedzane merytorycznym wstępem tłumaczenia konstytucji obecnie już 52 państw, „Zeszyty Ośrodka Informacji i Dokumentacji Europejskiej” (dziewięć numerów), „System Tezaurusów Biblioteki Sejmowej STEBIS” (23 zeszyty), publikacje towarzyszące organizowanym wystawom, czy słownik biograficzny Posłowie $i$ senatorowie Rzeczypospolitej Polskiej 1919-1939 (dotychczas cztery tomy obejmujące nazwiska na litery A-P). Ponadto na łamach czasopisma „Przegląd Sejmowy” publikowana jest od 1993 r. „Bibliografia Publikacji Sejmu, Senatu, Zgromadzenia Narodowego, Rzecznika Praw Obywatelskich, Trybunału Konstytucyjnego i Najwyższej Izby Kontroli”, dająca pełny obraz wydawnictw zwartych, ciągłych i urzędowych najważniejszych instytucji związanych z parlamentem. W związku z polską prezydencją w Radzie UE w 2011 r. BS wydała prekursorską na polskim rynku wydawniczym publikację, zawierającą przekłady pełnych tekstów konstytucji wszystkich państw Unii Europejskiej, zarówno w wersji książkowej, jak i elektronicznej. 
Realizacja nowych zadań po 1989 r. wymagała odpowiedniego wzmocnienia kadrowego. W tym czasie BS liczyła 37 pracowników, a późniejszy rozwój struktur i zmiana metod pracy (automatyzacja) wywołały konieczność zarówno zwiększenia, jak i przekwalifikowania personelu. Obok bibliotekarzy pojawili się muzealnicy, archiwiści, informatycy i specjaliści w zakresie europeistyki. W 2018 r. zatrudnionych było 70 osób w ogromnej większości o wysokich kwalifikacjach zawodowych. Od początku lat dziewięćdziesiątych przy rekrutacji do pracy oprócz wykształcenia brana jest pod uwagę potwierdzona certyfikatem znajomość języka obcego, a nowi pracownicy zobowiązani są do odbycia specjalnego rocznego szkolenia organizowanego przez Kancelarię Sejmu, tzw. zwanej aplikacji sejmowej.

Dla biblioteki parlamentarnej funkcjonującej w państwie unitarnym najbardziej naturalnymi partnerami do wymiany doświadczeń są inne biblioteki parlamentarne. Nie oznacza to oczywiście braku współpracy z bibliotekami krajowymi, ale podstawowe znaczenie mają relacje międzynarodowe ze względu na podobieństwo zarówno zasobów, kręgu użytkowników, jak i metod pracy. Jeszcze w latach czterdziestych, przed zapadnięciem żelaznej kurtyny, przedstawiciele BS zdołali uczestniczyć w dwóch konferencjach IFLA (Międzynarodowej Federacji Stowarzyszeń i Instytucji Bibliotekarskich, International Federation of Library Associations and Institutions), natomiast między rokiem 1950 a 1970 bezpośrednie kontakty międzynarodowe praktycznie ustały. Dopiero od 1978 r. przedstawiciel BS ponownie zaczął regularnie uczestniczyć w konferencjach IFLA i pracach sekcji bibliotek parlamentarnych, a stosunki z bibliotekarzami niektórych państw obozu komunistycznego (szczególnie Czechosłowacji i Węgier) oraz z państw nordyckich (Norwegii i Szwecji) trochę się ożywiły. Jakościowe zmiany w tej dziedzinie - podobnie jak w wielu innych — nastąpiły dopiero po zniesieniu barier politycznych w $1989 \mathrm{r}$.

Niemal od pierwszych lat przemian BS otrzymywała wsparcie ze strony parlamentów państw zachodnich. Szczególnie efektywna była pomoc Izby Reprezentantów Kongresu Stanów Zjednoczonych, tzw. program kongresmana Frosta, realizowany przez specjalny zespół Służby Badawczej Kongresu (Congressional Research Service), określany jako Frost Task Force pod merytorycznym kierownictwem Williama H. Robinsona. Kontynuowana do 1996 r. pomoc dla parlamentów 12 państw Europy Środkowej i Wschodniej obejmowała dostarczanie publikacji, sprzętu komputerowego, organizację szkoleń i seminariów. Działania te zmierzały do unowocześnienia bibliotek i stworzenia bezstronnego zaplecza informacyjnego i badawczego w objętych programem parlamentach. Procesy modernizacyjne wspomagane były także przez bibliotekę Izby Gmin oraz Parlament Europejski.

Późniejsza aktywność międzynarodowa BS zmierzała w kilku zasadniczych kierunkach: pierwszy to uczestnictwo w pracach sekcji bibliotek i służb badawczych parlamentów IFLA, drugi obejmuje różne formy aktywności w ramach Europejskiego Centrum Dokumentacji i Badań Parlamentarnych (ECPRD), którego korespondent rezydował w BS. W 1993 r. w Warszawie odbyła swoje XI spotkanie grupa robocza - Parlamentarne Biblioteki i Służby Badawcze. Przedstawiciel BS uczestniczył w pracach związa- 
nych z utrzymaniem i rozwijaniem tezaurusa EuroVoc, a jedno z seminariów poświęcone tezaurusowi w warunkach automatyzacji odbyło się w 1996 r. w Polsce. Również w Polsce w 1997 r. obradowała Sekcja Archiwów Parlamentarnych i Partii Politycznych Międzynarodowej Rady Archiwów (ICA), której BS jest członkiem. W latach 2004-2018 BS aktywnie uczestniczyła w Międzyparlamentarnej Wymianie Informacji w sprawach Unii Europejskiej (IPEX), a od 1993 r. bierze regularnie udział w pracach Międzynarodowego Konsorcjum Użytkowników Systemu Aleph (ICAU-IGeLU), co pozwala zarówno na bieżąco śledzić rozwój systemu, jak i lobbować na rzecz jego doskonalenia. W 1998 r. odbyło się w Polsce seminarium ICAU, którego gospodarzem była BS. $\mathrm{Z}$ ważniejszych programów międzynarodowych należy również wymienić projekt „ELVIL 2000 - Europejskiej Wirtualnej Biblioteki Legislacyjnej” (European Legislative Virtual Library). Program ten - finansowany przez Komisję Europejską, a koordynowany przez Bibliotekę Uniwersytecką w Sztokholmie — przyczynił się do poszerzenia dostępu do parlamentarnych baz danych oraz popularyzacji parlamentaryzmu, zwłaszcza wśród młodzieży wielu krajów Europy. Był on realizowany w latach 1999-2001, a jego polski komponent uzyskał wysoką ocenę przedstawiciela Komisji Europejskiej.

W 2008 r. nawiązano ścisłą współpracę z bibliotekami parlamentarnymi i służbami badawczymi krajów Grupy Wyszehradzkiej. W jej ramach odbywają się konferencje i seminaria. Stworzono też wielojęzyczny słownik terminów parlamentarnych. Zwieńczeniem tej współpracy jest projekt „Parlamentarna Biblioteka Cyfrowa Krajów Grupy Wyszehradzkiej" (V4DPL+), do którego w 2010 r. dołączyła także Austria. Pozycję BS w Międzynarodowej Federacji Stowarzyszeń i Instytucji Bibliotekarskich potwierdziło zoorganizowanie w 2017 r. (wraz z Biurem Analiz, Dokumentacji i Korespondencji Kancelarii Senatu) 33. konferencji Sekcji Bibliotek i Służb Badawczych Parlamentów IFLA. W trzydniowym spotkaniu w gmachu Senatu RP wzięło udział — nie licząc pracowników Sejmu i Senatu - 140 uczestników reprezentujących 49 państw ze wszystkich kontynentów. Hasło przewodnie brzmiało: „Informacja jako fundament solidarności społecznej: rola bibliotek parlamentarnych i służb badawczych”. Referaty, panele dyskusyjne i warsztaty szkoleniowe dotyczyły głównie zagadnień związanych z dostarczaniem obywatelom przejrzystej i szczegółowej informacji na temat prac legislacyjnych oraz innych działań parlamentów.

Obok wspomnianych form aktywności międzynarodowej BS uczestniczyła w wielu innych przedsięwzięciach, zawsze wychodząc z założenia, że jest to niezbędne do weryfikacji własnego poziomu przygotowania do realizacji zadań oraz pozwala korzystać z wiedzy i doświadczenia innych bibliotek parlamentarnych. Od połowy lat dziewięćdziesiątych w BS odbywają się szkolenia i staże dla pracowników ośrodków informacji i bibliotek krajów wschodnioeuropejskich i azjatyckich (Armenia, Azerbejdżan, Gruzja, Kambodża i in.), do organizowania których skłania nie tylko chęć podzielenia się zdobytą wiedzą, ale i pamięć o pomocy, z której korzystaliśmy na początku ostatniego trzydziestolecia.

Biblioteka Sejmowa od 100 lat wspiera polski parlament w pełnieniu funkcji ustawodawczej i kontrolnej. Zgromadzony zbiór parlamentariów już dziś stanowi i będzie 
stanowił w przyszłości podstawowe źródło wiedzy dla badaczy parlamentaryzmu, ustroju politycznego i prawa. Zachowanie i udostępnianie tego dziedzictwa z jednej strony i dostarczanie ustawodawcom aktualnej, pewnej i wszechstronnej informacji z drugiej, wyznacza cele i określa funkcje BS. Biblioteka w swoim obecnym kształcie organizacyjnym, nawiązującym do okresu II Rzeczypospolitej, wypełnia trzy zadania (biblioteki, archiwum i muzeum), które w sumie składają się na zaplecze informacyjno-dokumentacyjne Sejmu. Bogate i starannie sprofilowane zasoby biblioteczne, skrupulatnie gromadzona dokumentacja archiwalna oraz kolekcja dzieł sztuki i zabytków kultury materialnej pozwalają na udzielenie parlamentarzystom i innym użytkownikom odpowiedzi na ogromną większość pytań. Na podstawie zbiorów BS powstało w przeszłości i nadal powstaje wiele poważnych prac naukowych z zakresu prawa, politologii i historii.

Dzięki technice komputerowej korzystanie z zasobów BS już od dawna możliwe jest poza murami czytelni czy pracowni archiwalnej. Biblioteka od kilku lat jest również obecna i aktywna na portalach społecznościowych. Obok nowoczesnych form udostępniania informacji - szybkiego i pewnego, lecz niestety odhumanizowanego, BS umożliwia, zarówno posłom, jak i szerszej publiczności obcowanie z rękopisami, starodrukami, oryginalnymi dokumentami i dziełami sztuki. W działania te wpisuje się nadzór i realizacja na terenie gmachów sejmowych, jak i poza nimi, takich projektów artystycznych, jak tablice pamiątkowe, rzeźby, płaskorzeźby czy portrety osób ważnych dla historii parlamentaryzmu. Na licznych wystawach prezentowano polskie tradycje parlamentarne, istotne wydarzenia w historii Sejmu i w historii Polski. Ekspozycje w Sejmie, na Zamku Królewskim w Warszawie, w Helsinkach, Wilnie, Rydze, Strasburgu i Brukseli zmierzały do przybliżenia zwiedzającym nie tylko faktów historycznych, lecz również ducha i kolorytu mniej czy bardziej odległych idei i wydarzeń. Pamięć o tradycji w połączeniu z dążeniem do wykorzystywania najnowszych technik informacyjnych stanowi rys charakterystyczny dnia dzisiejszego BS. Ocenę, czy synteza ta jest udana, pozostawiamy naszym Czytelnikom.

\section{BIBLIOGRAFIA}

AKTY PRAWNE, PARLAMENTARIA, DOKUMENTY WEWNĘTRZNE

Sejm Ustawodawczy II RP. Wniosek posła J. Dąbskiego i tow. z klubu PSL „Piastowców” w sprawie utworzenia bibljoteki Sejmowej, druk nr 229, marzec 1919 r.

Sejm Ustawodawczy II RP. Wniosek (w sprawie projektu ustawy skarbowej wraz z preliminarzem państwowym na czas od 1 stycznia do 30 czerwca 1919 r.), druk nr 402, kwiecień $1919 \mathrm{r}$.

Informacja o wysokości środków przeznaczonych na urządzenie Biblioteki, Sejm II RP, okres I, Sprawozdanie stenograficzne z 32. posiedzenia Sejmu Rzeczypospolitej z dn. 12 kwietnia 1923 r., 1. 6-7.

Propozycja przekazania Bibliotece Sejmowej części księgozbioru byłego Wydziału Krajowego we Lwowie w trakcie dyskusji nad projektem ustawy o przekazaniu Uniwersytetowi Jana Kazimierza we Lwowie budynku posejmowego (w zbiorach BS). 
Sejm II RP, okres II. Sprawozdanie Komisji Budżetowej o preliminarzu budżetowym Sejmu i Senatu na rok budżetowy1929/1930, druk nr 400, cz. 2, styczeń 1929 r.

Sejm II RP, okres II. Sprawozdanie Komisji Budżetowej o preliminarzach budżetowych Sejmu i Senatu na rok budżetowy 1930/31, druk nr 700, cz. 2a i 2b, styczeń 1930 r.

Zarządzenie Marszałka Sejmu z dnia 29 września 1931 r. — Statut Organizacyjny Biura Sejmu Rzeczypospolitej (Biblioteki dotyczy rozdz. III: Bibljoteka i Archiwum Sejmu i Senatu); M.P. z 1931 r. nr 234, poz. 318.

Zarządzenie Marszałka Senatu z dnia 29 września 1931 r. - Statut Organizacyjny Biura Senatu Rzeczypospolitej (Biblioteki dotyczą § 9-11); M.P. z 1931 r. nr 234, poz. 319.

Sejm II RP, okres III. Sprawozdanie Komisji Budżetowej o preliminarzu budżetowym Sejmu (część 2-a) i Senatu (część 2-b) na rok budżetowy 1932/1933, druk nr 441, cz. 2, styczeń $1932 \mathrm{r}$.

Sejm II RP, okres III. Sprawozdanie Komisji Budżetowej o preliminarzach budżetowych Sejmu (część 2-a) i Senatu (część 2-b) na rok 1933/34, druk nr 640, cz. 2a i 2b, styczeń 1933 r.

Sejm II RP, okres III. Sprawozdanie Komisji Budżetowej o preliminarzach budżetowych Sejmu (część 2-a) i Senatu (część 2-b) na rok 1934/35, druk nr 800, cz. 2a i 2b, styczeń 1934 r.

Sejm II RP, okres III. Sprawozdanie Komisji Budżetowej o preliminarzach budżetowych Sejmu (część 2-a) i Senatu (część 2-b) na rok 1935/36, druk nr 1000, cz. 2a i 2b, styczeń 1935 r.

Sejm II RP, kadencja IV. Sprawozdanie Komisji Budżetowej o preliminarzach budżetowych Sejmu (część 2a) i Senatu (część 2b) na rok 1936/37, druk nr 55, cz. 2a i 2b, luty 1936 r.

Sejm II RP, kadencja IV. Sprawozdanie Komisji Budżetowej o preliminarzach budżetowych Sejmu (część 2a) i Senatu (część 2b) na rok 1937/38, druk nr 300, cz. 2a i 2b, luty 1937 r.

Sejm II RP, kadencja IV. Sprawozdanie Komisji Budżetowej o preliminarzach budżetowych Sejmu (część 2a) i Senatu (część 2b) na rok 1938/39, druk nr 700, cz. 2a i 2b, luty 1938 r.

Sejm II RP, kadencja V. Sprawozdanie Komisji Budżetowej o preliminarzach budżetowych Sejmu (część 2a.) i Senatu (część 2b) na rok 1939/40. Druk nr 100, cz. 2a i 2b. Warszawa, luty 1939.

Pismo Przewodniczącego Krajowej Rady Narodowej Bolesława Bieruta z 14 listopada 1944 r. do Kierownika Resortu Pracy, Opieki Społecznej i Zdrowia w sprawie przekazania książek zmagazynowanych przez okupantów w gmachu, przy ul. Chopina 28A w Lublinie do dyspozycji Biura Prezydialnego Krajowej Rady Narodowej d1a Bib1ioteki Krajowej Rady Narodowej (kopia maszynopisu w zbiorach BS).

Pismo Szefa Biura Prezydialnego Krajowej Rady Narodowej dr Leona Kurowskiego z 28 listopada 1944 r. do Biblioteki im. H. Łopacińskiego w Lublinie z prośbą o pomoc w organizacji Biblioteki Krajowej Rady Narodowej (kopia odpisu w zbiorach BS).

Biblioteka Sejmowa, Sprawozdanie z działalności za rok 1947, Warszawa 1948 (maszynopis w zbiorach BS).

Projekt Tymczasowego Statutu Organizacyjnego Biura Sejmu Ustawodawczego RP, Warszawa 1948 (kopia maszynopisu w zbiorach BS. Biblioteki dotyczą § 6, 12-14).

Protokół Narady Bibliotecznej zwołanej przez ob. Marszałka Sejmu Ustawodawczego RP dn. 21 października 1949 r. o godz. 13, Warszawa 1949 (maszynopis w zbiorach BS. Omówiono m.in. zasady polityki gromadzenia księgozbioru).

Hryniewicz Z., Narada biblioteczna w Sejmie [21 października 1949 r.], Warszawa 1949 (maszynopis w zbiorach BS. Artykuł przygotowany do ewentualnego druku, zawierający omówienie zwołanej przez marszałka Sejmu Ustawodawczego narady w sprawie BS).

Zarządzenie Ministra Oświaty z dnia 2 września 1950 r. w sprawie gromadzenia, przechowywania i wyjątkowego udostępniania w bibliotekach druków wycofanych z obrotu, M.P. z 1950 r. nr A-99, poz. 1249, ze zm.

Wytyczne pracy Biblioteki Sejmowej na rok 1953, oprac. Z. Hryniewicz, Biblioteka Sejmowa, Warszawa 1953 (maszynopis w zbiorach BS). 
Sprawozdanie z pracy Biblioteki za rok 1953. Plan pracy na rok 1954, oprac. Z. Hryniewicz, Biblioteka Sejmowa, Warszawa 1954 (maszynopis w zbiorach BS).

Konferencja na temat „Polityka kompletowania księgozbioru”: projekt referatu, akceptowany przez Z. Hryniewicz, Biblioteka Sejmowa, Warszawa 1957 (maszynopis w zbiorach BS).

Jasińska M., Piusińska W., Romańska A., Biblioteka Sejmowa: stan obecny, wnioski, propozycje: raport Komisji Bibliotekarzy-Ekspertów, Warszawa 1972 (maszynopis w zbiorach BS).

OPRACOWANIA, ARTYKUŁY

Chmielewska-Gorczyca E., Eurovoc in Poland: the system of thesauri in the Sejm Library, [w:] Eurovoc Seminar '95, Prague, June 27-28, IFLA, Prague 1995.

Chwalewik E., Zbiory polskie: archiwa, bibljoteki, gabinety, galerje, muzea i inne zbiory pamiatek przeszłości w ojczyźnie i na obczyźnie: $w$ zestawieniu alfabetycznym wedtug miejscowości, t. 2, Biblioteka Sejmu i Senatu, Warszawa 1927.

Grobelska K., Meble i wnętrza Jana Bogustawskiego, „Architektura” 2002, nr 5.

Hryniewicz Z., Biblioteka Sejmowa: sprawozdanie za 5-lecie 1944-1949 r., „Bibliotekarz” 1950, nr 3-4.

Karamać B., The Sejm Library - the Library of the Polish Parliament, „Polish Libraries Today” 1997, t. 4.

Karamać B., Library of the Polish Sejm, [w:] Parliamentary libraries and research services in Central and Eastern Europe, IFLA Publications 87, München 1998.

Kramm J., Henryk Kołodziejski jako bibliotekarz: wspomnienie, „Przegląd Biblioteczny” 1955, z. 2.

Kreczmar M., Poset w bibliotece: komputeryzacja Biblioteki Sejmowej usprawni prace naszych ustawodawców, „Computerworld Polska” 1996, nr 37.

Kulisiewicz W., The Sejm Library 1919-2009, [w:] The Czech Parliamentary Library: a tribute on its 150th anniversary: the Central European parliamentary libraries from the past to present, red. Karel Sosna, Imprint, Praga 2009.

Kulisiewicz W., The Sejm Library 1919-2009, „Library Trends” 2010, nr 58(4), https://doi.org/ 10.1353/lib.2010.0010.

Mężyński A., Okupacyjne dzieje księgozbioru Biblioteki Sejmowej, „Przegląd Sejmowy” 1994, nr 4.

Mężyński A., Kommando Paulsen: Organisierter Raub polnischer Kulturgüter während des Zweiten Weltkrieges, Köln 2000.

Nauka Polska, oprac. S. Demby, Bibljoteka Sejmu i Senatu, Warszawa 1927, t. 7.

Parlament Rzeczypospolitej Polskiej 1919-1927, red. H. Mościcki, W. Dzwonkowski, Bibljoteka Sejmu i Senatu, Warszawa 1928.

Próchnicka Maria, Rola Biblioteki Sejmowej w procesie obstugi informacyjnej parlamentarzystów, „Zeszyty Naukowe UJ. Prace z Bibliotekoznawstwa i Informacji Naukowej” 1995, z. 2. 